\title{
Seismic imaging of dyke swarms within the Sorgenfrei-Tornquist Zone (Sweden) and implications for thermal energy storage
}

\author{
Alireza Malehmir ${ }^{1}$, Bo Bergman ${ }^{2, \mathrm{a}}$, Benjamin Andersson ${ }^{3}$, Robert Sturk ${ }^{3}$, and Mattis Johansson ${ }^{2, \mathrm{a}}$ \\ ${ }^{1}$ Dept. of Earth Sciences, Uppsala University, Uppsala, Sweden \\ ${ }^{2}$ Sweco Environment AB, Malmö, Sweden \\ ${ }^{3}$ Skanska Sverige AB, Malmö, Sweden \\ apresently at: WSP, Malmö, Sweden
}

Correspondence: Alireza Malehmir (alireza.malehmir@geo.uu.se)

Received: 8 August 2018 - Discussion started: 7 September 2018

Revised: 17 November 2018 - Accepted: 1 December 2018 - Published: 14 December 2018

\begin{abstract}
There is a great interest and demand for greentype energy storage in Sweden for both short- and longterm (hours, days, weeks and seasons) periods. While there are a number of approaches proposed (e.g., compressed air, geothermal and thermal), only a few have commercially been demonstrated through upscaling projects. Among these, the thermal energy storage (TES) that stores energy (excess heat or cold) in fluids is particularly interesting. The excess energy can be stored underground in excavated caverns and used for large district heating and cooling purposes as well as for balancing and regulating electrical energy in power grids. For an upscaling underground TES project within the Tornquist suture zone of Scania in the southwest of Sweden, three high-resolution seismic profiles, each approximately $1 \mathrm{~km}$ long, were acquired. Geologically, the site sits within the southern margin of the Romeleåsen fault zone in the Sorgenfrei-Tornquist Zone (STZ), where dolerite dyke swarms of Carboniferous-Permian age are observed striking in the SE-NW direction for hundreds of kilometers both on land and in offshore seismic and magnetic data (from Scania to Midland Valley in the UK). These dykes, 10-50 m thick, in the nearby quarries (within both Precambrian gneiss and quartzite) express themselves mostly in a subvertical manner. They can therefore act as a good water/fluid barrier, which can be an important geological factor for any TES site. For the data acquisition, combined cabled and wireless recorders were used to provide continuity on both sides of a major road running in the middle of the study area. Bedrock depressions are clearly depicted in the tomograms, suggesting the possibility of zones of weaknesses, highly fractured
\end{abstract}

and/or weathered, in the bedrock and confirmed in several places by follow-up boreholes. Several steeply dipping (60$65^{\circ}$ ) reflections were imaged down to $400 \mathrm{~m}$ depth and interpreted to originate from dolerite dykes. This interpretation is based on their orientations, strong amplitudes, regular occurrences and correlation with downhole logging data. In addition, groundwater flow measurements within the unconsolidated sediments and in bedrock suggest steeply dipping structures are the dominant factor in directing water mainly along a SE-NW trend, which is consistent with the strike of the dyke swarm within the STZ. To provide further insight on the origin of the reflections, even the historical crustalscale offshore BABEL (Baltic and Bothnian Echoes from the Lithosphere) lines (A-AA-AB) were revisited. Clear multiphase faults and signs of intrusions or melt source in the lower crust are observed, as well as a Moho step across the Tornquist zone. Overall, we favor that the reflections are of dolerite origin and their dip component (i.e., not subvertical) may imply a Precambrian basement (and dykes) tilting, block rotation, towards the $\mathrm{NE}$ as a result of the Romeleåsen reverse faulting. In terms of thermal storage, these dykes then may be encountered during the excavation of the site and can complicate underground water flow should they be used as a fluid barrier in case of leakage. 


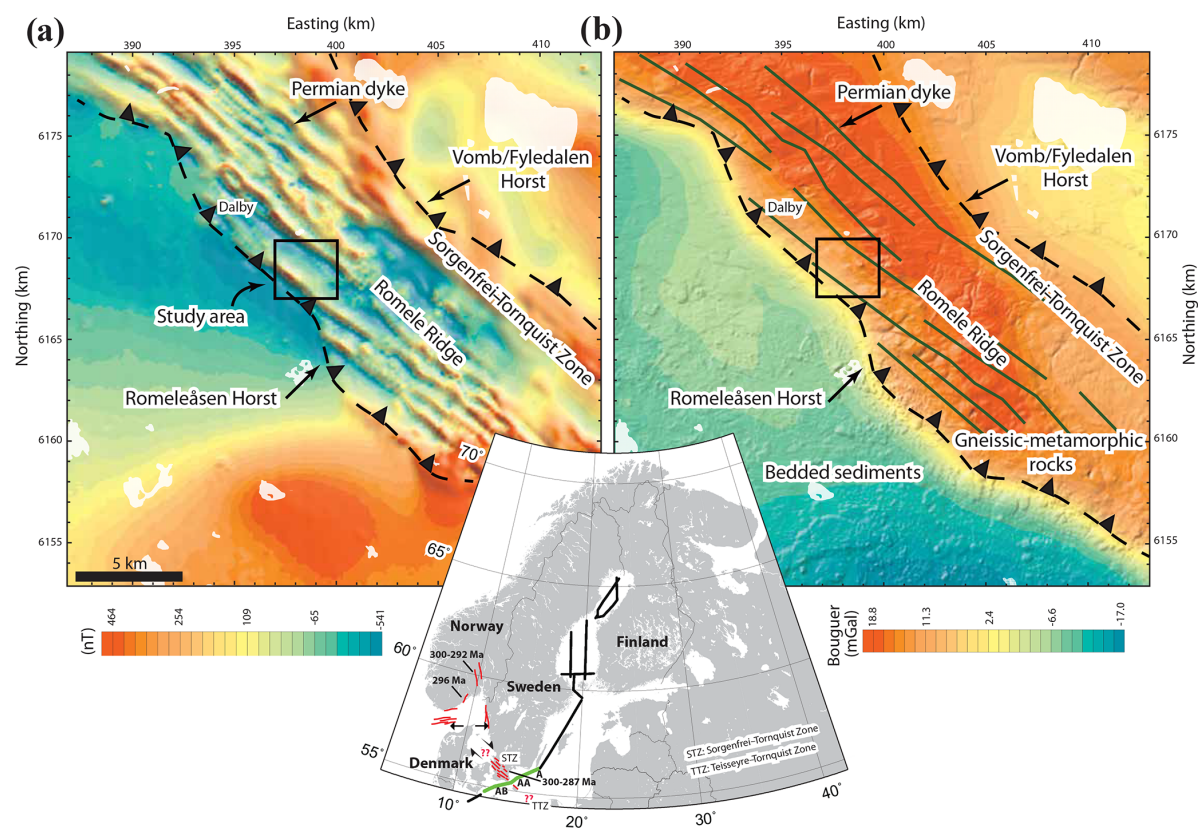

Figure 1. (a) Aeromagnetic anomaly and (b) bouguer gravity maps of the Scania region of Sweden showing the location of the study area south of the town of Dalby. Magnetic lineaments clearly mark the location of Permian dyke swarms within the Sorgenfrei-Tornquist Zone (STZ), which is a horst structure within an active strike-slip tectonic setting. The inset map shows the interpreted location of the dyke swarms of the same generation within the STZ. Dyke orientations and ages are based on Phillips et al. (2017, and references therein). In this work, historical offshore BABEL (Baltic and Bothnian Echoes from the Lithosphere) lines A-AA-AB (green lines in the inset map) have also been revisited and results discussed. Aeromagnetic and gravity data were kindly provided by the Geological Survey of Sweden.

\section{Introduction}

Demand and interest for renewable energy is rapidly increasing worldwide, although with some temporal fluctuations, in order to reduce $\mathrm{CO}_{2}$ emissions and also to provide a sustainable, cheaper and alternative source of energy to the market (e.g., International Energy Agency, 2018; Alva et al., 2018; Inglesi-Lotza and Dogan, 2018). In Sweden, through a number of initiatives and cutting-edge technologies, a number of companies aim to upscale their ideas to provide largedistrict heating and cooling systems for both short- and longterm purposes. For example, the Skanska company has invented (Skanska Sverige AB, 2013; Pilebro et al., 2016) the idea of underground energy storage based on the mechanism that thermoses keep hot and cold water for a long period of time (thermal energy storage or TES). This builds on the physical principle of "hot water floating on cold water" (Håkansson, 2016), allowing excess energy to be collected and used later, or simply for balancing energy consumption between daytime and nighttime. The concept, however, requires field demonstration, large-scale underground developments (Skanska Sverige AB, 2013) and facilities where good control and suitable subsurface geology are present. Thermal energy is stored in a fluid (e.g., water) in tanks or an excavated cavern. The cavern then is insulated by suitable geology (impermeable rocks) or through concrete walls. Since different fluids can be considered for this purpose (e.g., flu- ids used in low-temperature systems), leakage and accidents must be avoided or leaked fluids must be safely and quickly removed in case of an accident. A suitable TES site should be close to consumers, in our case the cities of Lund and Malmö, and have access to excess heat or cold as well as electrical energy (e.g., European Spallation Source (ESS) in Lund).

To support such a development in the subsurface (at a depth of about $300 \mathrm{~m}$ ), we conducted a seismic survey near the town of Dalby in Lund within the Scania Tornquist suture zone (Fig. 1) in southwest Sweden during August 2015. The site is situated close to the RFZ (Romeleåsen fault/thrust and flexure zone) with a complex geologic and tectonic history (Erlström and Sivhed, 2001). Near-vertical dykes are observed from several quarries in the area crosscutting graniticgneissic-amphibiotic rocks and form distinct magnetic lineaments in the regional data (Fig. 1). These dykes likely have also acted as surfaces on which further faulting (until the present day) has occurred. They are doleritic (diabase) in composition, Permian in age (Torsvik et al., 2008) and can be followed through the Scania region of Sweden and through offshore seismic data reported from the southern North Sea (Heeremans et al., 2004; Phillips et al., 2017 and references therein).

The seismic survey had an initial objective of identifying depth to bedrock and if major bedrock undulations could be related to zones of weaknesses (fractured or/and altered) in 
bedrock. Nevertheless, given the high-fold seismic data acquired and rich reflectivity observed in the raw shot gathers, reflection data processing complemented the refraction data analysis. In this work, we show a series of northeast steeply dipping reflections that surrounds the planned underground storage and speculate whether their origins are of dolerite dykes. Furthermore, we revisited the historical offshore BABEL (Baltic and Bothnian Echoes from the Lithosphere) lines A-AA-AB (BABEL Working Group, 1990, 1993; Fig. 1) in an attempt to check if these dykes were also observable. From this, we provide better images of a potential source region for the dykes and a necking (keel or step) zone at the Moho level across the Tornquist zone that was proposed by Mazur et al. (2015) as a result of a collision between two Precambrian terranes with different crustal thicknesses.

\section{Geology of the Sorgenfrei-Tornquist Zone (STZ)}

The Trans-European suture zone or Tornquist zone in general is a major crustal-scale boundary in Europe that separates the Precambrian East European Craton from the Phanerozoic orogens of southwestern Europe. In the Scania (Skåne) of Sweden and northern Denmark, it is a major strike-slip feature (Fig. 1), reactivated many times through its history and tectonic inversion, and referred to as the SorgenfreiTornquist Zone (STZ), while in northern Poland it is referred to as the Teisseyre-Tornquist Zone (TTZ). It is traditionally thought to be the boundary of the lithospheric plate of Baltica that existed between the late Neoproterozoic and early Paleozoic (Cocks and Torsvik, 2005). A crustal keel approximately $20 \mathrm{~km}$ wide associated with a Moho step has been inferred based on a major gravity low across the zone in Poland by Mazur et al. (2015); see also Thybo (2000), Grad et al. (2002), Malinowski et al. (2005) and Guterch and Grad (2006). Offshore seismic data suggest that the Tornquist zone extends to the southern Norwegian North Sea (Pegrum, 1984). Based on the results from the BABEL offshore seismic data, a number of authors have proposed that the Tornquist zone is a listric fault under the Hanö Bay basin (e.g., Blundell, 1992; Erlström et al., 1997; Thybo, 2000; Meissner and Krawczyk, 1999). According to Meissner et al. (2002), during the Late Cretaceous, tectonic inversion of a rigid upper mantle led to large-scale compressive tectonics. Within the Tornquist zone, this led to a series of reverse faults in the upper crust as a result of transferring stress in the lower ductile crust undergoing buckling to the upper crust (see also Sopher et al., 2016 and references therein). The Hanö Bay basin (see section of BABEL A-AA in Fig. 1) formed as a result of syn-inversion extension (pull-apart basin due to fault curvature or an extension) associated with significant strikeslip faulting in the Tornquist zone (Blundell, 1992).

Structurally, the most striking geological feature in the Scania area is the Romeleåsen horst, which stretches over (a) $\mathrm{s}$

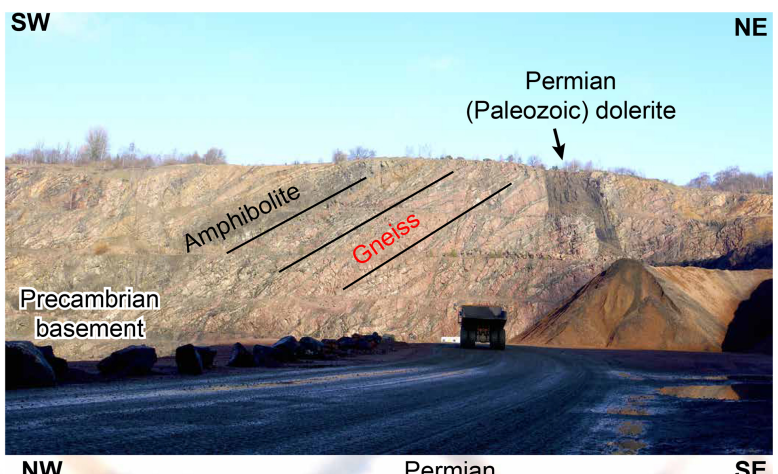

(b)

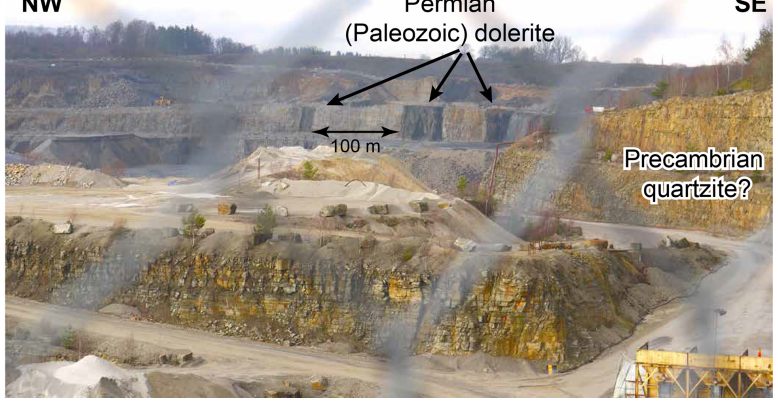

Figure 2. Example photos showing typical doleritic dykes within the Scania area (a) from the Dalby rock quarry (about $500 \mathrm{~m}$ north of the study area) and (b) a quartzite quarry (about $2 \mathrm{~km}$ northwest of the study area). The dykes appear, $10-50 \mathrm{~m}$ thick, in a regular order typically $50-100 \mathrm{~m}$ far apart and crosscut stratigraphy and amphibolites. They tend to be subvertical in most places that they have been observed on land. In the Dalby quarry, these dykes make up to $5 \%$ of the rocks excavated. Gneiss and amphibolite are abundant and typically equality constitutes the remaining bulk volume of the excavated rocks. Photos are from Alireza Malehmir (July 2015).

$30 \mathrm{~km}$ along the STZ. It was formed by fault reactivations in the Tornquist zone during Mesozoic and Tertiary compression (Bergerat et al., 2007). The town of Dalby is situated on the southwestern margin of the Romeleåsen reverse fault system. Together with the Vomb-Fyledalen fault system (reverse), the area between these fault systems is uplifted (Romele Ridge) and is the main reason for the gravity high (basement high) observed in the region (Fig. 1b).

Lithologically, in the Scania area, rocks are primarily composed of Proterozoic gneiss-amphibolite (nearly $50 \%-50 \%$ volumetrically) to sedimentary rocks of various ages. In the Dalby quarry north of the study area, amphibolites dip often towards the southwest as lens-shaped lenticular bodies (Fig. 2a). Evidence of faulting and hydrothermal activity is evident in the quarry. A dominant feature, however, is the Permo-Carboniferous doleritic (mafic) dykes crosscutting gneissic-amphibolitic rocks (Fig. 2a) and sometimes quartzitic (metamorphosed bedded sandstone) rocks in the area (Fig. 2b). They occur in a regular order, often 5-20 m thick, generally striking in the NW-SE direction, as evident in the magnetic data over the Scania area (Fig. 1a). While often these dykes are considered to be subvertical, some- 


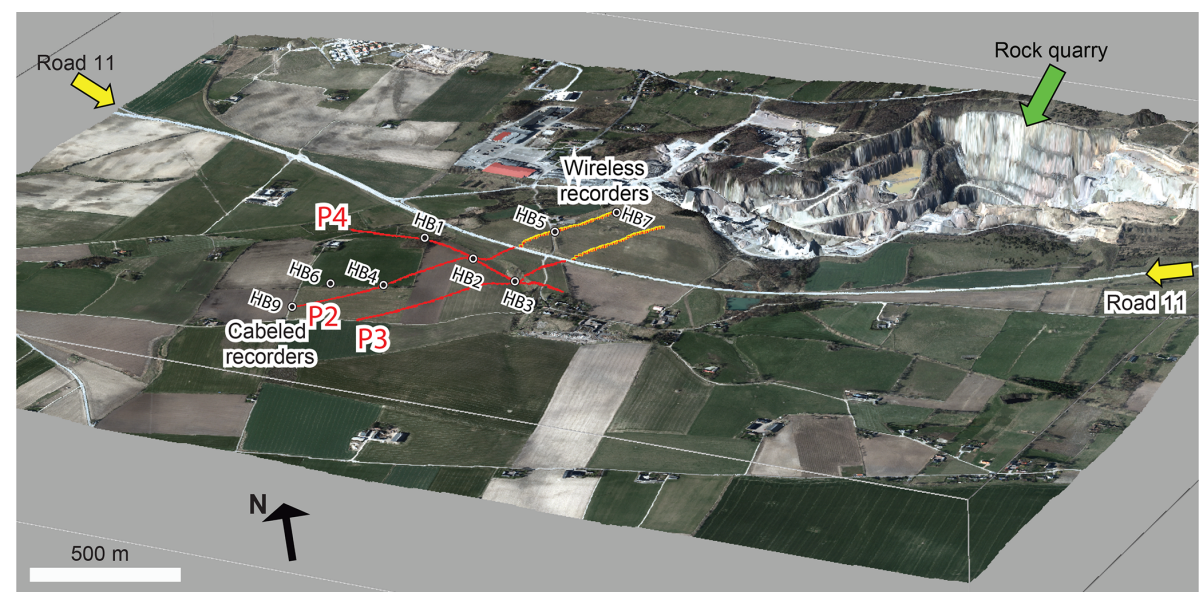

Figure 3. Locations of the seismic profiles (P2, P3 and P4), in Dalby (southern Sweden), draped onto the high-resolution lidar elevation surface of the study area. A combination of cabled and wireless recorders was used for the data acquisition to allow long-offset recording and to overcome issues related to the high-speed Road 11. Black filled-in circles are the drilled boreholes (after the seismic data acquisition) in the study area.

times, in field photos from nearby quarries, they appear to be steeply dipping (e.g., Bergerat et al., 2007). Phillips et al. (2017) observe the same generations of the dykes (320$270 \mathrm{Ma}$ ) in the southern Norwegian North Sea albeit as dipping reflections (35-50 north dipping) and argue for the role of tectonic inversion (faulting) and basin-basement flexure (block rotation) for their current geometry. They also suggest the dyke swarm is part of a major magmatic system (mantle plume) that has a radial shape extending for over $800 \mathrm{~km}$ connecting to those observed in the Midland Valley dyke suite (302-292 Ma) in the UK.

\section{Seismic survey}

\subsection{Seismic data acquisition}

Three high-resolution, $5 \mathrm{~m}$ shot and receiver spacing using 141-172 receivers, refraction and reflection seismic profiles were acquired over 5 days: 2 days for profile $4,1.5$ days for profile 2 and 1.5 days for profile 3 (Fig. 3). Profile 3 was not in the original plan but was acquired at the site because of its position and being parallel to profile 2, where geological structures (e.g., dyke systems) are favorable in this orientation instead of the perpendicular one. Some delays with the seismic source and noise due to wind caused problems when acquiring the data along profile 4 . A Bobcat-mounted drop hammer $(500 \mathrm{~kg})$ was used to generate the seismic signal (e.g., Place et al., 2015). To provide continuity from one side of the road to another, 51 wireless recorders connected to $10 \mathrm{~Hz}$ geophones and operating in an autonomous mode were used (Fig. 3). In total, approximately $2.6 \mathrm{~km}$ long reflection seismic data were acquired.

GPS times of the source impacts (microsecond accuracy) recorded on the cabled sensors (also $10 \mathrm{~Hz}$ geophones) were used to extract the data from the wireless recorders, and then these were merged together. Three shot records per source position were generated and vertically stacked to improve signal-to-noise ratio. Noise from the high-speed Road 11 and cars passing was at times significant but the vertical stacking of the repeated shots helped to partly cancel this noise. On occasion, due to the proximity to the Malmö airport, airplane noise was also significant and led to delays in the data acquisition. Table 1 summarizes some of the main acquisition parameters used in this study.

Figure 4 shows a collection of photos taken during the seismic survey and the equipment used. Although Road 11 runs through the middle of the study area, the seismic data show excellent quality particularly along profiles 2 and 3 , and are slightly noisy, due to high wind, along profile 4.

Figures 5a and 6a show examples of shot gathers after vertical stacking of the three repeated shot records (three hits at every shot location) from profiles 2 and 3, respectively. The quality of the data is excellent and only some noise from the cars and wind in Fig. 5a is notable. The first breaks are clear in the merged cabled and wireless shot records, suggesting that refraction data analysis and velocity tomography are possible using the data. There are also weak signs of reflections in the data, which justify their processing and imaging as reflection seismic sections. As it will be presented later, most reflections dip towards the northeast, implying that the wireless recorders and shooting on the northern side of Road 11 were necessary to enable their imaging. Without shooting (in particular) and recording there, we would not have been able to provide images of most of the reflections observed in the data. 
Table 1. Main seismic acquisition and refraction parameters of the Dalby data (August 2015). DGPS indicates differential GPS. Root mean square is indicated by rms.

\begin{tabular}{llll}
\hline Spread parameters & Profile 2 & Profile 3 & Profile 4 \\
\hline Recording system & Sercel Lite & Sercel Lite & Sercel Lite \\
Survey geometry & Fixed & Fixed & Fixed \\
No. of receivers & $172(2001-2122,2501-2551)$ & $166(3001-3113,3501-3551)$ & 141 (4001-4141) \\
No. of shots & 170 (three records/point) & 157 (three records/point) & 120 (three records/point) \\
Shot/receiver spacing & $5 \mathrm{~m}$ & $5 \mathrm{~m}$ & $5 \mathrm{~m}$ \\
Maximum offset & $\sim 900 \mathrm{~m}$ & $\sim 850 \mathrm{~m}$ & $\sim 800 \mathrm{~m}$ \\
Source type & $500 \mathrm{~kg}$ Bobcat drop hammer & $500 \mathrm{~kg}$ Bobcat drop hammer & $500 \mathrm{~kg}$ Bobcat drop hammer \\
Geophone & $10 \mathrm{~Hz}$ spike & $10 \mathrm{~Hz}$, spike & $10 \mathrm{~Hz}$, spike \\
Sampling interval & $0.5 \mathrm{~ms}$ & $0.5 \mathrm{~ms}$ & $0.5 \mathrm{~ms}$ \\
Record length & $20 \mathrm{~s}(1 \mathrm{~s}$ used for processing) & $20 \mathrm{~s}(1 \mathrm{~s}$ used for processing) & $20 \mathrm{~s}(1 \mathrm{~s} \mathrm{used} \mathrm{for} \mathrm{processing)}$ \\
Wireless data harvesting & GPS time & GPS time & GPS time \\
Total no. of traces & 29240 & 26062 & 16920 \\
Geodetic surveying & DGPS & DGPS & DGPS \\
\hline Refraction parameters & & 24429 & 14620 \\
\hline No. of first breaks & 23419 & $2-\mathrm{D}$ ray tracing and 3-D first & 2 -D ray tracing and 3-D first \\
Method & $2-\mathrm{D}$ ray tracing and 3-D first & break travel-time tomography \\
& break travel-time tomography & break travel-time tomography & $5 \times 20 \times 2 \mathrm{~m}$ \\
Cell sizes $(x, y, z)$ & $5 \times 10 \times 2 \mathrm{~m}$ & $5 \times 10 \times 2 \mathrm{~m}$ & 8 \\
No. of iterations & 8 & 8 & $2.7 \mathrm{~ms}$ \\
rms & $2.4 \mathrm{~ms}$ & $2.4 \mathrm{~ms}$ & \\
\hline
\end{tabular}

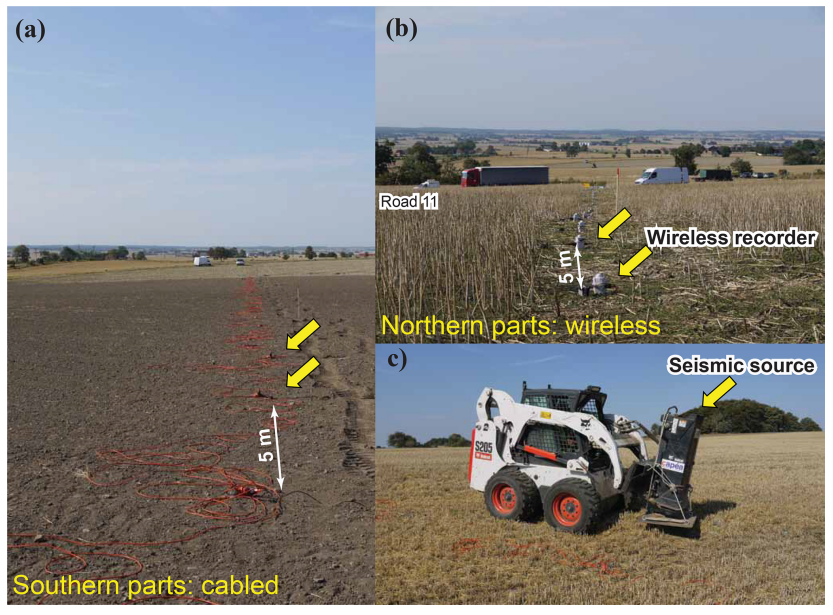

Figure 4. Field photos showing how the seismic data were acquired using a combination of (a) cabled and (b) wireless recorders (connected to $10 \mathrm{~Hz}$ geophones). (c) A $500 \mathrm{~kg}$ Bobcat-mounted drop hammer was used as the seismic source. Only at a few locations close to Road 11 and on the eastern side of profile 4 when farming was not finished was shooting not permitted.

\subsection{Reflection data processing}

Signs of reflections in the raw shot gathers were encouraging and satisfied processing the reflection component of the data. Reflections along profile 4 have, for example, different characters and are shorter and more gently dipping, compared with those observed along profiles 2 and 3 (Fig. 5), suggesting that the main dip favors the orientation of profiles 2 and 3 , i.e., striking NW-SE and dipping NE. Table 2 summarizes the key steps used for the reflection data processing of the seismic data. The 2-D processing was employed given the straight nature of the profiles. Several factors were considered during the processing. To avoid processing artifacts, the processing was kept simple and parameters were obtained carefully (e.g., Dehghannejad et al., 2012; Malehmir et al., 2017). The important processing steps were refraction static corrections (Figs. 5b and 6b), prestack data enhancement (Figs. 5c and 6c) and velocity analysis. Velocity analysis was important because of the steep nature of the reflections. Example raw shot gathers (from profiles 2 and 3 ) and how reflections were enhanced in shot gathers are shown in Figs. 5 and 6 . The processed shot gathers show a number of parallel steeply dipping reflections in both profiles. Data along the SW portion of profile 3 were excluded since they did not allow good imaging of the dipping reflections to the NE (not favoring this dip and quite noisy due to strong winds during the data acquisition). Because of this, we also tested a number of ways to enhance the quality of the reflections such as the use of normal amplitude stacking and diversity-based stacking. 

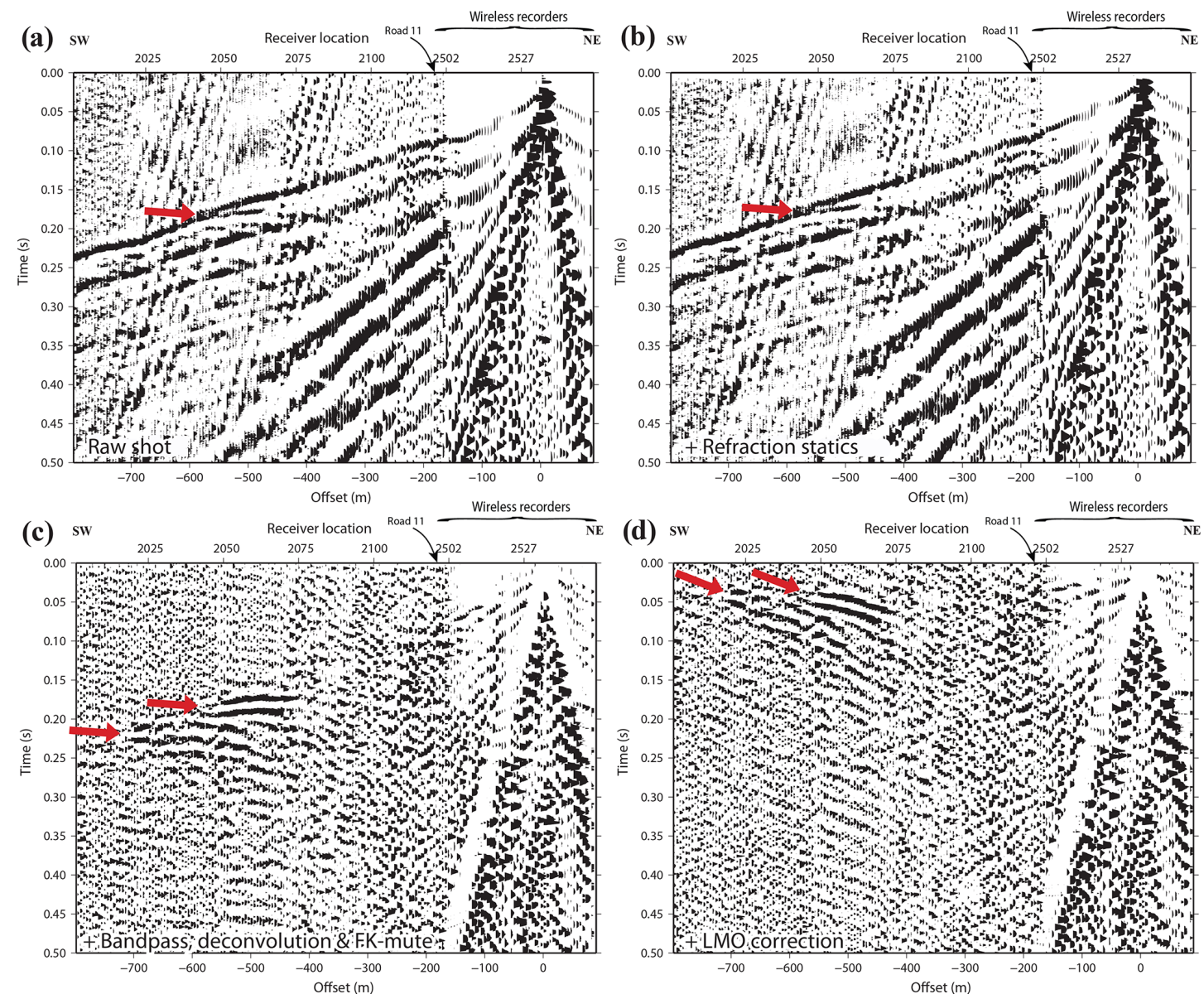

Figure 5. (a) An example shot gather from profile 2 (after vertical stacking of the three repeated shot records) showing the quality of the first breaks and how merged cabled and wireless data were used for both refraction data analysis and reflection data processing. Note the high level of noise from Road 11 remained as surface-wave energy (steep or low velocity) but was also a noticeable reflection (dipping towards the northeast) in the raw data that became much stronger after (b) refraction static corrections, (c) prestack data enhancement (two sets of reflections) and (d) linear move-out (LMO) corrections (for display purpose). Two sets of reflections (marked by red arrows in panel d) are notable between receivers 2020-2040. The application of a median filter and dip filter (FK filter linked with linear move-out correction) helped to enhance these reflections in prestack gathers significantly.

Along profile 3, we concluded that the diversity stack provided a more superior image than the normal amplitude stack (Fig. 7) likely because the noise level (wind and noise from car traffic) was higher when data were acquired along this profile. Along profiles 2 and 4, the normal amplitude stack was used.

Reflection seismic sections can be presented as unmigrated and migrated seismic sections. When reflections have considerable dip, migration should be done to bring them to their actual locations in the 2-D space (assuming no out-ofthe-plane effect). To migrate stacked sections, velocity data are needed; we used a constant velocity of $4000 \mathrm{~ms}^{-1}$ for both migration and time-to-depth conversion. This implies that reflections may be slightly steeper (on the order of $5^{\circ}$ ) and deeper if this velocity was too low, and velocities on the order of $5000 \mathrm{~ms}^{-1}$ should have been used instead (Yilmaz, 2001). Migration along profile 4 was done using a phase-shift algorithm, while for the other two profiles a finite-difference algorithm was used. Unmigrated seismic sections are shown for data quality control purposes and the reflections observed there do not represent actual locations of the geological features nor are dips true. Along profile 3, on the portion where data were excluded, prior to the migration, dummy traces were added to allow the steeply dipping reflections to be imaged in the muted region.

\subsection{Refraction data analysis and correlation with borehole data}

In our study, both refraction data analysis (for refraction static corrections) and tomographic methods were employed. First breaks were picked manually and corrected where needed. We estimate an error on the order of $2 \mathrm{~ms}$ (based on reciprocal times) in the picking accuracy. Along profile 
Table 2. Key reflection processing steps (Globe Claritas ${ }^{\mathrm{TM}}$ processing software was used for the processing). Terms in the table are defined as follows: SEGD: Society of Exploration Geophysicists field data, CDP: common depth point, FK: frequency-wavenumber domain, NMO: normal moveout, AGC: automatic gain control, FX: frequency space domain.

\begin{tabular}{|c|c|c|c|}
\hline Steps & Profile 2 & Profile 3 & Profile 4 \\
\hline 1 & Read SEGD data & Read SEGD data & Read SEGD data \\
\hline 2 & $\begin{array}{l}\text { Zero-time correction (automatic and } \\
\text { manually corrected) }\end{array}$ & $\begin{array}{l}\text { Zero-time correction (automatic and } \\
\text { manually corrected) }\end{array}$ & $\begin{array}{l}\text { Zero-time correction (automatic and } \\
\text { manually corrected) }\end{array}$ \\
\hline 3 & Vertical shot stacking & Vertical shot stacking & Vertical shot stacking \\
\hline 4 & Geometry setup (CDP spacing $2.5 \mathrm{~m}$ ) & Geometry setup (CDP spacing $2.5 \mathrm{~m}$ ) & Geometry setup (CDP spacing $2.5 \mathrm{~m}$ ) \\
\hline 5 & First break picking & First break picking & First break picking \\
\hline 6 & Refraction static corrections & Refraction static corrections & Refraction static corrections \\
\hline 7 & Elevation static $\left(4000 \mathrm{~ms}^{-1}, 95 \mathrm{~m}\right)$ & Elevation static $\left(4000 \mathrm{~ms}^{-1}, 95 \mathrm{~m}\right)$ & Elevation static $\left(4000 \mathrm{~ms}^{-1}, 95 \mathrm{~m}\right)$ \\
\hline 8 & Band-pass filter $(20-40-180-220 \mathrm{~Hz})$ & Band-pass filter $(20-40-180-220 \mathrm{~Hz})$ & Band-pass filter (20-40-160-280 Hz) \\
\hline 9 & Deconvolution (22 m gap) & Deconvolution (22 m gap) & Deconvolution (22 m gap) \\
\hline 10 & FK filter & FK filter & FK filter \\
\hline 11 & Median filter (linked to NMO) & Median filter (linked to NMO) & Median filter (linked to NMO) \\
\hline 12 & AGC $(200 \mathrm{~ms})$ & $\operatorname{AGC}(200 \mathrm{~ms})$ & AGC $(200 \mathrm{~ms})$ \\
\hline 13 & Residual static corrections & Residual static corrections & Residual static corrections \\
\hline 14 & NMO corrections ( $30 \%$ stretch mute) & NMO corrections ( $30 \%$ stretch mute) & NMO corrections ( $30 \%$ stretch mute) \\
\hline 15 & Stack (normal) & Stack (diversity) & Stack (normal) \\
\hline 16 & FX decon & FX decon & FX decon \\
\hline 17 & Balance amplitude & Balance amplitude & Balance amplitude \\
\hline 18 & Padding & Padding & \\
\hline 19 & $\begin{array}{l}\text { Migration } \quad \text { (finite } \quad \text { difference, } \\
4000 \mathrm{~ms}^{-1} \text { ) }\end{array}$ & $\begin{array}{l}\text { Migration } \quad \text { (finite } \quad \text { difference, } \\
4000 \mathrm{~ms}^{-1} \text { ) }\end{array}$ & Migration (phase shift, $4000 \mathrm{~ms}^{-1}$ ) \\
\hline 20 & $\begin{array}{l}\text { Time-to-depth conversion (constant } \\
4000 \mathrm{~ms}^{-1} \text { ) }\end{array}$ & $\begin{array}{l}\text { Time-to-depth conversion (constant } \\
4000 \mathrm{~ms}^{-1} \text { ) }\end{array}$ & $\begin{array}{l}\text { Time-to-depth conversion (constant } \\
4000 \mathrm{~ms}^{-1} \text { ) }\end{array}$ \\
\hline 21 & $\begin{array}{l}\text { Export for plotting and 3-D visualiza- } \\
\text { tion }\end{array}$ & $\begin{array}{l}\text { Export for plotting and 3-D visualiza- } \\
\text { tion }\end{array}$ & $\begin{array}{l}\text { Export for plotting and 3-D visualiza- } \\
\text { tion }\end{array}$ \\
\hline
\end{tabular}

2, approximately 23500 first breaks, profile 3 approximately 24500 first breaks and profile 4 approximately 14500 first breaks (Table 1) were used for the first break travel-time tomography (Fig. 8). A diving-wave finite difference based 3D travel-time tomography code (Tryggvason et al., 2002 and references therein) was used for this purpose. Cells along the profile directions were $5 \mathrm{~m}$, perpendicular $10 \mathrm{~m}$ and at depth $2 \mathrm{~m}$. Eight iterations were used to invert the data. A smooth 2-D velocity model ranging from 300 to $5000 \mathrm{~ms}^{-1}$ with constant gradient honoring the topography was used as the starting model. We used a velocity of $300 \mathrm{~ms}^{-1}$ to represent the air velocity and in order to avoid rays channeling above the topography during the iterations. Smoothing constraints were used but gradually relaxed towards the final iteration numbers. The final velocity models show rms values around $2-3 \mathrm{~ms}$ as shown in Fig. 8. These rms values are acceptable given the estimated error in the picking.

The final tomographic velocity models are shown in Fig. 9 for all the three profiles. There is a good correspondence between low-velocity depressions and bedrock surface depressions, as indicated by the drilling results conducted after the seismic survey suggesting that the tomographic velocity models can be used to constrain the bedrock surface with a good level of confidence. Rocks in general show on aver- age low velocities (3000-4000 $\mathrm{ms}^{-1}$ ) except in a few places and in particular at a major topographic depression (ditch) in the study area (B2 and B3 in Fig. 9). This is unusual for crystalline-type rocks (Salisbury et al., 2003; Malehmir et al., 2013) and may imply an overall average-to-poor quality of rocks in this area; however, it is expected from our observations in the nearby quarry and rocks situated within the highly tectonized Tornquist zone. The velocity model of profile 4 does not show significant velocity variations but shows a good correspondence where profile 2 is intersected but less where profile 3 is intersected. Where profile 3 is intersected, the velocity model of profile 4 better resolves the bedrock surface.

At places where bedrock is intersected at greater depths than usual, for example, at $25 \mathrm{~m}$ depth by borehole HB5 (e.g., A2 in Fig. 9a), small-valley looking bedrock is clearly observed in the tomograms, suggesting a possibility for major weakness zones (likely highly fractured and/or weathered) in the bedrock. This interpretation is supported by both drill cuttings and low velocities observed in these regions. 

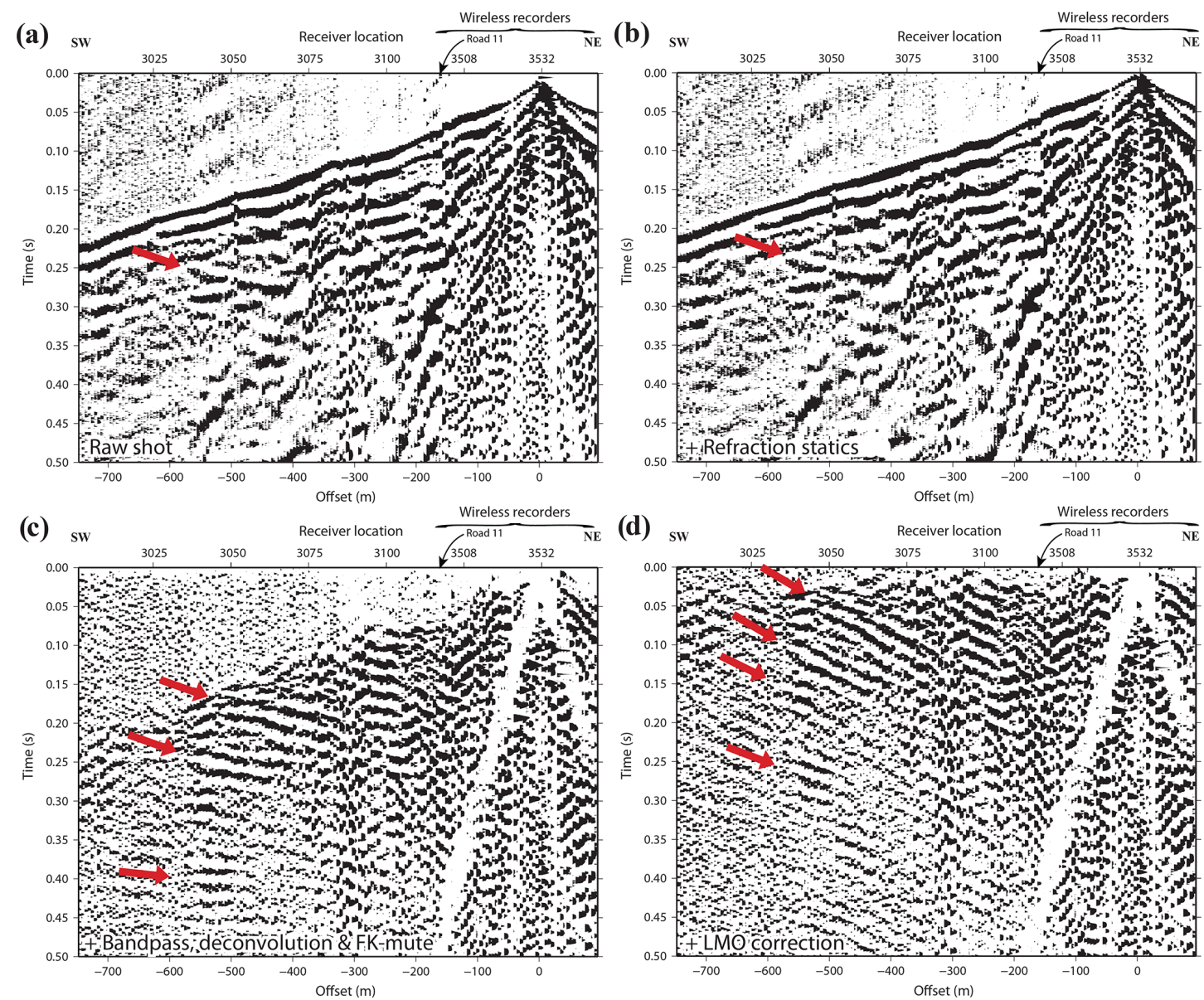

Figure 6. (a) An example shot gather from profile 3 (after vertical stacking of the three repeated shot records) illustrating the quality of the first breaks and the data. Note a clear reflection (dipping towards the northeast) already in the raw data (red arrow) but much stronger after (b) refraction static corrections, (c) prestack data enhancement and (d) LMO corrections (for display purpose). A series of reflections (marked by the red arrows in panels $\mathbf{c}$ and $\mathbf{d}$ ) is notable between receivers 3025 and 3075.

\section{Follow-up drilling, ground magnetic survey and downhole logging}

Immediately after the seismic survey and for better understanding the hydrogeological conditions (baseline) at the site, a series of boreholes (Fig. 3) was drilled. A rotary percussion-drilling rig was used for this purpose, which did not allow core sampling but rather drill cuttings to be analyzed. This choice was justified economically and for the purpose of hydrological studies requiring wide-diameter boreholes. Before performing pump tests and estimating hydrological parameters, a number of boreholes were downhole logged using natural gamma, caliper (borehole diameter), density and resistivity probes. Immediately after this, the holes had to be sealed off with no possibility to conduct more surveys given their positions in an operating farm. Downhole logging results were provided to us for this study for HB2, HB3 and HB5 (Fig. 3). For all the other boreholes, depth to bedrock was provided as shown in Fig. 9. Important drilling observations were also provided. We will mention later that a suitable situation would have been to measure magnetic susceptibility and core drilling in the area. Inclined core drilling was planned to be a follow-up stage; however, it did not continue due to issues with land accessibility. It would be important for the seismic interpretations to distinguish Permian mafic dykes from faults and amphibolites. Caliper would be useful if severe faulting is encountered, as well as resistivity and density measurements. Density between dolerite and amphibolite is usually similar, and they both should show low gamma radiations. Ground total-field magnetic survey using a 2-D profiling approach along the seismic profiles was also conducted and used in this study.

\section{Results and interpretation}

Several northeast-dipping, approximately $60-65^{\circ}$ reflections were imaged down to $400 \mathrm{~m}$ depth thanks to the close shot and receiver spacing strategy of the data acquisition as well 

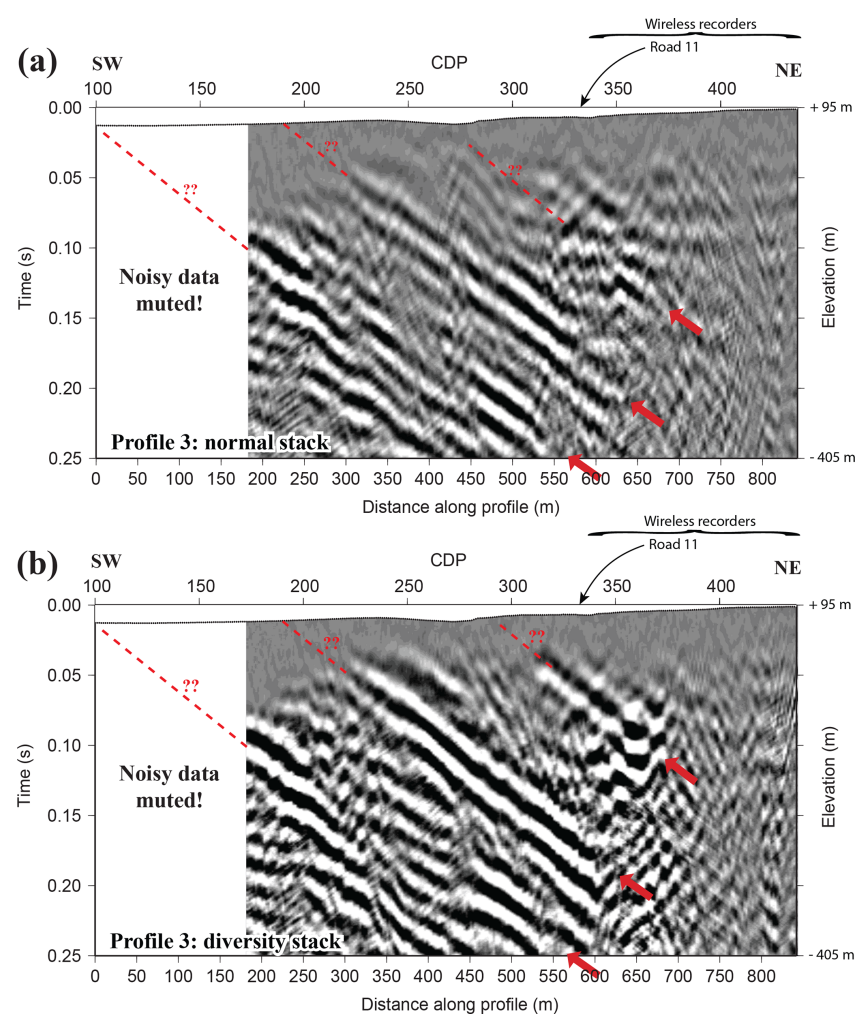

Figure 7. Comparison between (a) normal amplitude stack and (b) diversity-based stack on the data along profile 3 illustrating much better quality imaging of the reflections obtained using diversity stack. Note that the northeastern-most reflection marked by a red arrow is very notable in panel (b). Dashed lines provide a possible projection of the reflections towards the surface. Data on the southernmost portion of the profile were noisy and hence excluded from the stacking.

as long offsets provided by the use of wireless recorders. These reflections often show coherent character but on occasion such as along profile 4 are discontinuous and have different appearances. Figures 10 and 11 show unmigrated and migrated seismic sections of profiles 2 and 3, respectively. For profile 4 (Fig. 12), the migrated section is quite noisy; thus, results along this profile need to be carefully interpreted along with the stacked section. Tomographic velocity models are also plotted together with the reflection seismic sections to check if velocity anomalies are associated with any of the reflections.

A careful inspection of the results suggests subparallel reflections dipping about $60-65^{\circ}$ towards the NE along both profiles 2 and 3; they have similar characters except close to the central parts of profile 2 slightly towards its SW parts (Fig. 10b). One particular reflection, R3, is associated with a topographic depression. Reflections along profile 4 have gentler dips, as one would expect, given the steep character of the reflections in the perpendicular direction (profiles 2 and 3). They may, however, suggest the general strike is not perpendicular to the direction of profiles 2 and 3. Reflections along profile 4 are shorter and have a disturbed character in the middle of the profile. This may be due to the noisy nature of the data along this profile or suggest different geological structures than those observed along profiles 2 and 3 . Along profile 4 , some evidence of down faulting can be seen from the discontinuity of the reflections and their bivergentwedge appearance (Fig. 12). This may be due to the Protogine zone, which strikes through the area in a NNE-SSW direction. Movements along this fault zone are earlier (0.9$1 \mathrm{Ga})$ than in the Tornquist zone but may very well have influenced tectonic setting in the area in conjunction with the movements along the Tornquist zone.

Based on a series of reasons, we argue the steeply dipping reflections mainly originated from the Permian dolerite dykes. These include the following. (1) The reflections are subparallel and favor the orientations observed in the magnetic data (Fig. 1a) and occasionally match the magnetic highs observed in the ground measurements (e.g., R2 in Figs. 10 and 11). (2) They have strong seismic amplitudes as observed already in the shot gathers and appear in a regular order of $100 \mathrm{~m}$ apart (Fig. 2); this can be expected from 10 to $50 \mathrm{~m}$ thick dolerite dykes given their high density and velocity (e.g., Juhlin, 1990; Planke and Cambray, 1998; Salisbury et al., 2003; Planke et al., 2005). (3) We rule out a gneissic-amphibolitic origin because they are rather part of the medium and do not appear to be isolated-individual entities to be imaged (Fig. 2a); they are nearly volumetrically equally present and hence can only act as a medium for other geological features to be imaged using seismic frequencies. (4) With 2-D considerations and possibly better adjustments of velocities during the migration and time-to-depth conversion, the reflections fit regions of decrease in natural gamma (e.g., Malehmir and Bellefleur, 2010) and increase in density observed in the downhole logging data (see the insets in Figs. 10 and 11). For example, along profile 2, density and natural gamma logs (Fig. 10c) show a reasonable correlation with the position of reflection R2 ( $5 \mathrm{~m}$ vertically thick zone). Resistivity logs show a drop in the resistivity but likely suggest the dyke-country rock contact is highly water bearing and thus electrically conductive. The caliper log shows no variations in this region, helping to exclude a possibility for a fault at this location in conjunction with a high-density zone. Borehole HB5 also shows a drop in the natural gamma (15 m vertically thick zone) associated with the reflection $\mathrm{R} 4$ along profile 2 (Fig. 10b). Along profile 3, borehole HB3 shows a vertically thicker region where reflection $\mathrm{R} 2$ may be connected to a reduced natural gamma zone (Fig. 11c), likely a dolerite dyke.

To help better understand the 3-D geometry of the reflections, we first visualized them in 3-D and then picked the reflections as observed in the migrated seismic sections (Fig. 13a). Visualization was done in conjunction with the tomography results (Fig. 13b). Again, a careful inspection of this figure suggests a major NW-SE trend for most of the re- 
(a)
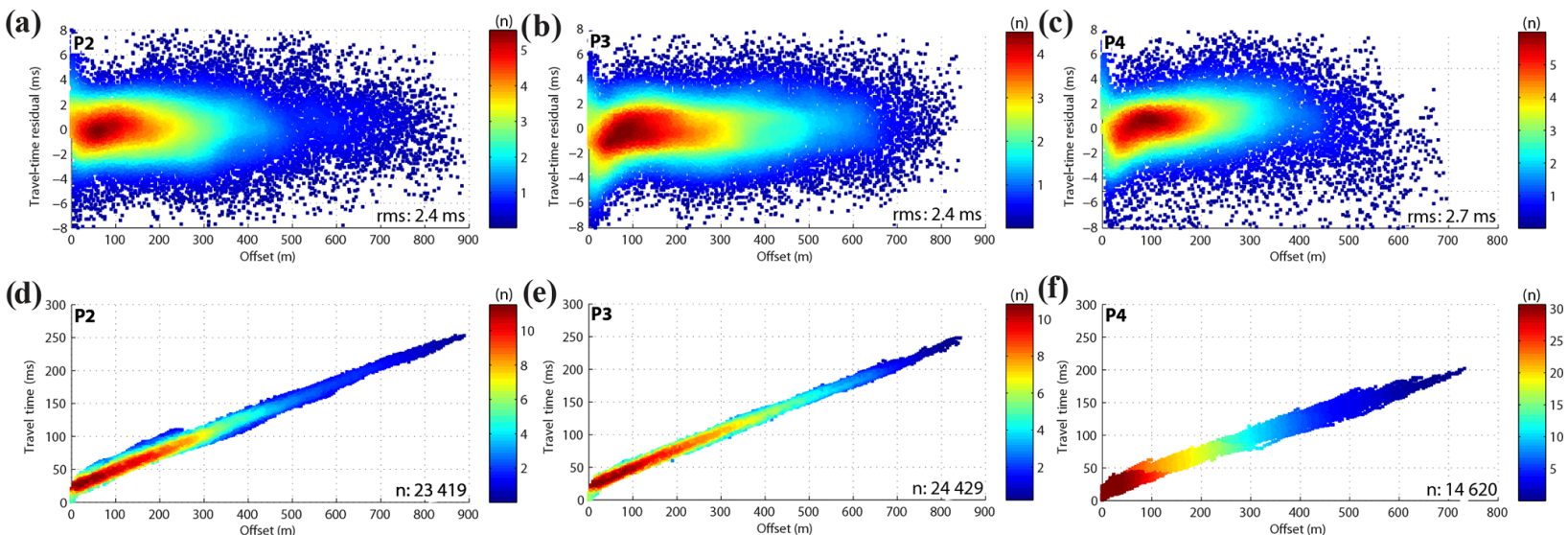

Figure 8. Plots of the travel-time residuals (rms misfit) obtained after eight iterations for (a) profile 2, (b) profile 3 and (c) profile 4 . The first picked breaks as a function of offsets along profiles $2-4$ are shown in panels (d)-(f), respectively. Note that profile 4 is shorter than profiles 2 and 3. Different colors represent different data density.
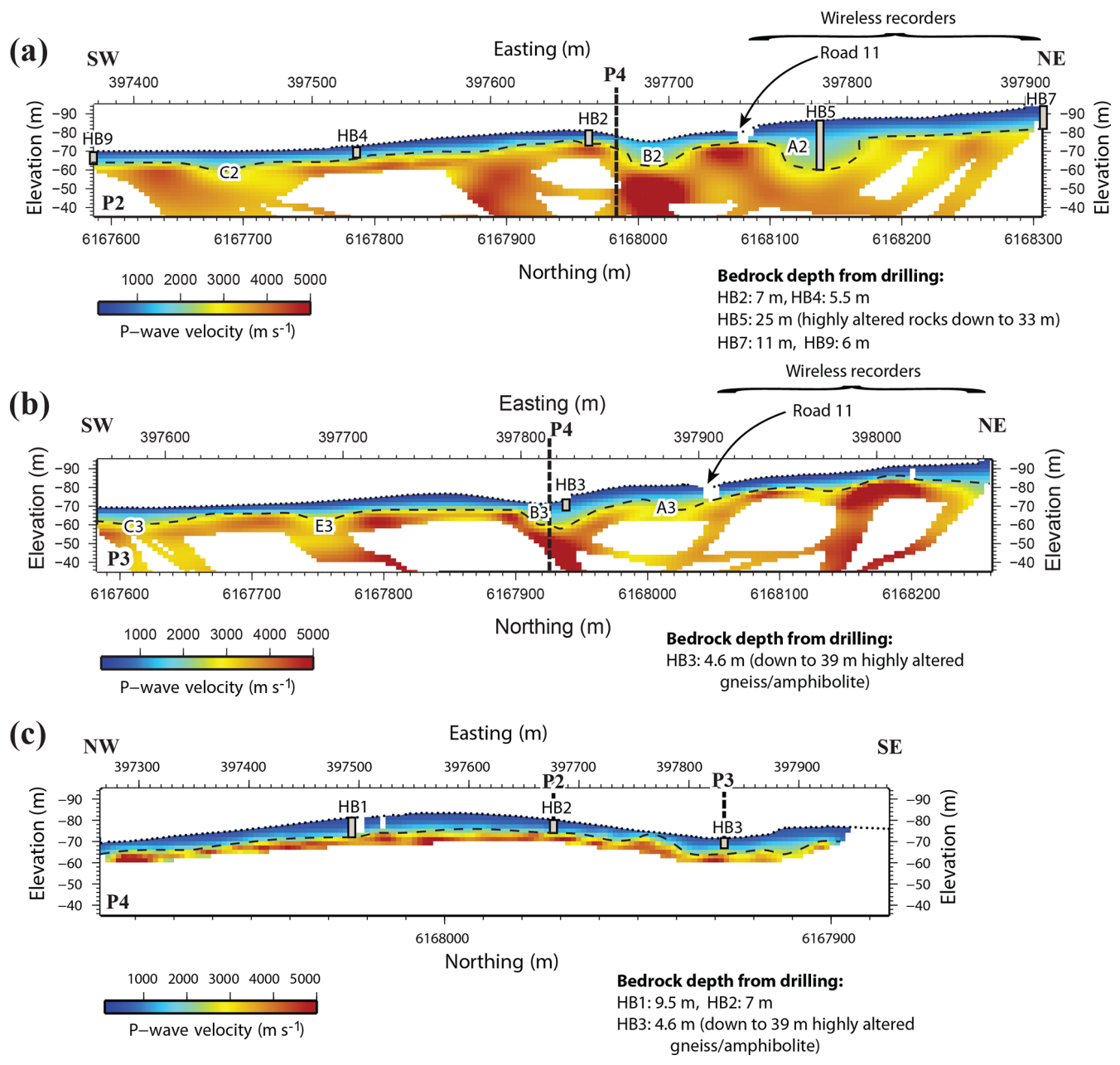

Figure 9. First break travel-time tomography model along (a) profile 2, (b) profile 3 and (c) profile 4, showing the undulating nature of bedrock (dashed line) and correlation with the bedrock surfaces identified from follow-up drilling at the site. Low-velocity depressions are notable in areas labeled by A2-3, B2-3, C2-C3 and E3 particularly along profile 2. The poorest quality rocks and deepest bedrock were observed at the location of A2 (HB5), where down to $33 \mathrm{~m}$ depth only highly altered rocks were observed from the drill cuttings (i.e., no core drilling was performed). 
(a)

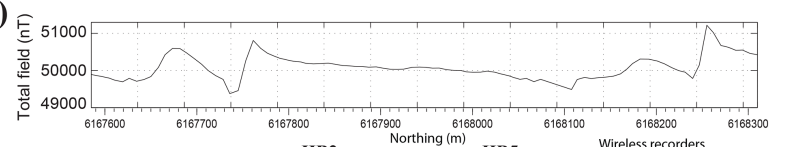

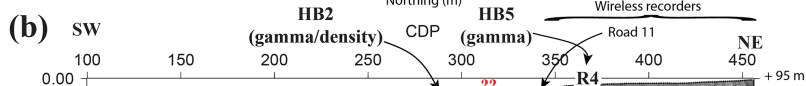
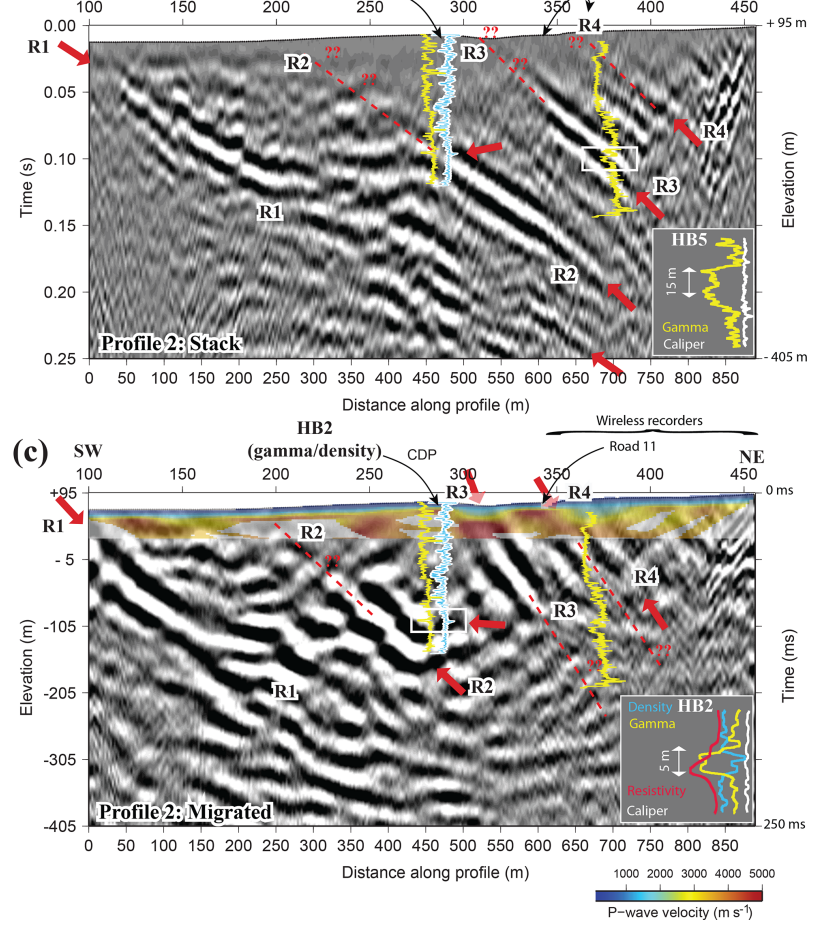

Figure 10. (a) Ground total-field magnetic, (b) unmigrated and (c) migrated (also time-to-depth-converted) reflection seismic sections along profile 2 . The tomographic velocity model is projected onto the migrated section for direct comparison. Red arrows mark the main reflections. They may extend at depth but we are unable to image them due to the short length of the profile. Downhole logging results from boreholes HB2 and HB5 suggest that the reflections R2 and R3 are associated with the zone of reduced natural gamma, high density and low resistivity. The caliper log suggests no change in the borehole diameter. Based on these, we argue that the reflections originated from dolerite dykes.

flections, and this strike is consistent with the dyke swarms formed during the Permo-Carboniferous breakup of Pangaea in Scania (Obst and Katzung, 2006), as shown in Fig. 1. Based on these, we identified four major sets of reflections (R1-R4; Fig. 13) that we interpret to originate from dolerite dykes.

\section{Discussion}

A fundamental surprise in this study is why the dolerite dykes, if our interpretation is correct, are inclined and not subvertical as observed in most quarries in the north of the study area (e.g., Fig. 2b). Through a series of arguments, we further discuss this and what this may imply in terms of ge- (a)
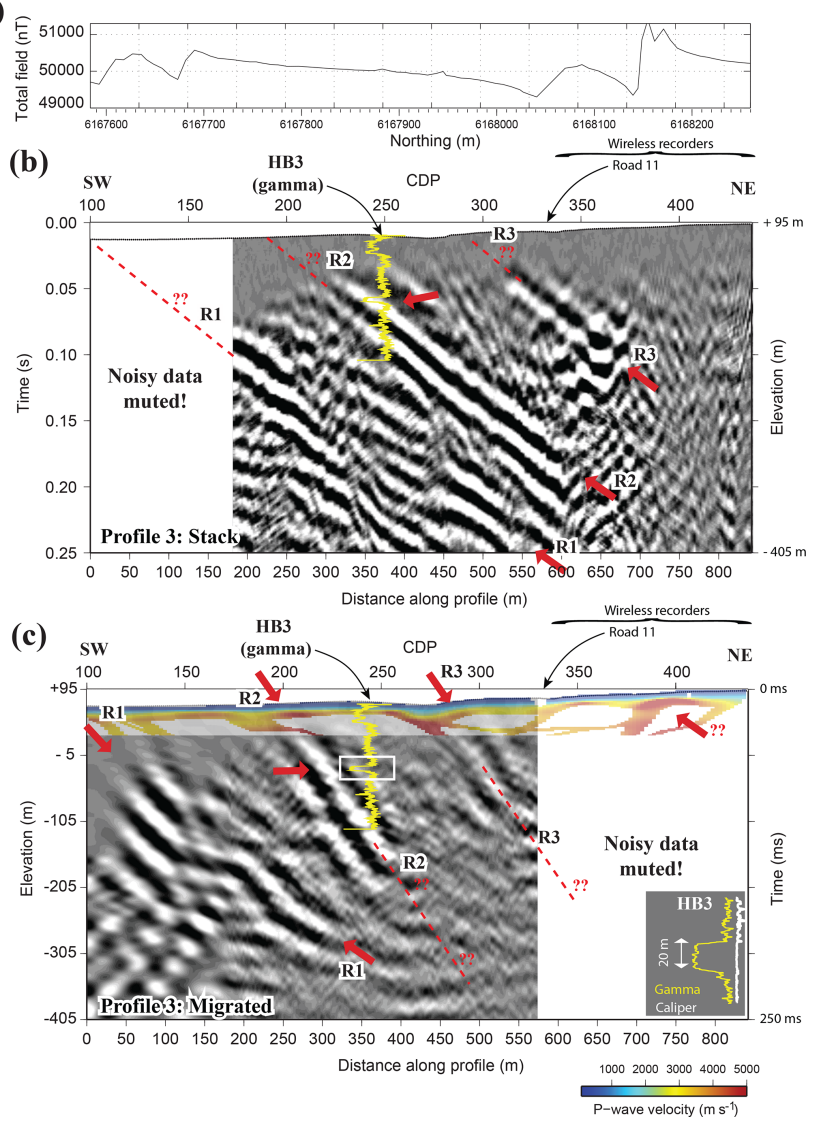

Figure 11. (a) Ground total-field magnetic, (b) unmigrated and (c) migrated (also time-to-depth-converted) reflection seismic sections along profile 3 . The tomographic velocity model is projected onto the migrated section for direct comparison. Red arrows mark the reflections. They may extend at depth but we are unable to image them due to the short length of the profile. Downhole logging results from borehole HB3 suggest that the reflection R2 is associated with the zone of reduced natural gamma. The caliper log suggests no change in the borehole diameter. Based on these, we argue that the reflection originated from a dolerite dyke.

ology and its significance for developing the thermal storage site in the study area. Prior to this, we discuss resolution of the seismic data based on our judgment of how thick they are from the boreholes and frequency content of the data. Given a dominant frequency of $100 \mathrm{~Hz}$ and a background velocity of $4000 \mathrm{~ms}^{-1}$, we estimate a vertical resolution on the order of $10 \mathrm{~m}$. The detection limit would be then on the order of a couple of meters. This implies dykes of 1-2 m thick can still be detected but not resolved. Judging from the thicknesses observed on the logging data (5-20), it appears we are unable to fully resolve the top and bottom of the dykes; hence, we are inclined to suggest the seismic data have at best a vertical resolution on the order of 15-20 m. With high resolution in this study, we also refer to the fine source and receiver spacing, as well as the reasonably high seismic fold (75-90) used. 
(a)
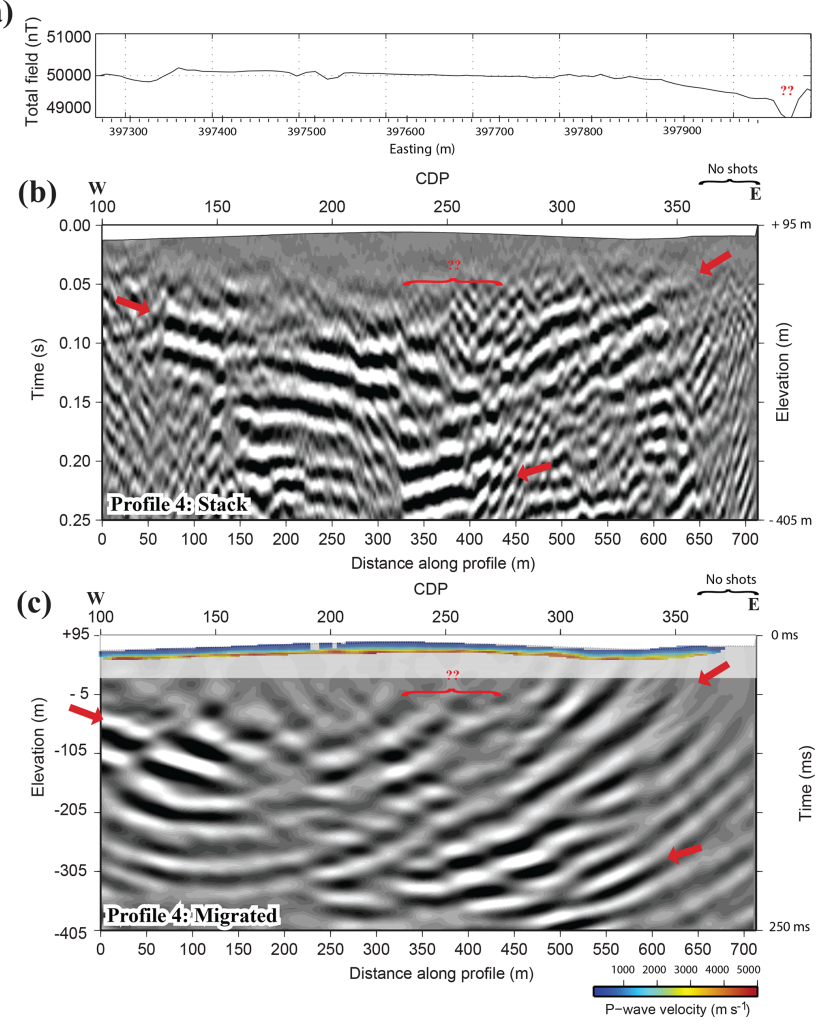

Figure 12. (a) Ground total-field magnetic, (b) unmigrated and (c) migrated (also time-to-depth-converted) reflection seismic section of profile 4 . The tomographic velocity model is projected onto the migrated section for direct comparison. Red arrows mark the reflections that appear to be divergent and in the middle of the profile more horizontal. The central part of the profile shows indications of down faulting.

\subsection{Hydrogeology of the site}

Two different hydrological measurements were conducted to check underground water flow in the study area. The first one measured the groundwater table in the sediments through existing boreholes and wells (Fig. 14a), and the second one measured the groundwater table through boreholes that intersected the bedrock (Fig. 14b). The motivation was to check if any particular pattern in the groundwater flow can be associated with the geological structures in the area. As one can expect, the measurements in the sediments (Fig. 14a) suggest a groundwater flow dominantly towards the lower elevations (water table at about $53 \mathrm{~m}$ elevation) in the area with the central part of profile 4 being on a hill (red contours showing the water table at about $82 \mathrm{~m}$ elevation). The measurements in the bedrock, however, provided much more interesting results, a pattern for the groundwater flow dominantly towards the SE (Fig. 14b) and an orientation consistent with the directions of the dykes between reflections R1 and R2 (Fig. 1a) and a bit more complicated between reflections R3 and R4. We think the interpreted down faulting system (a fault run-

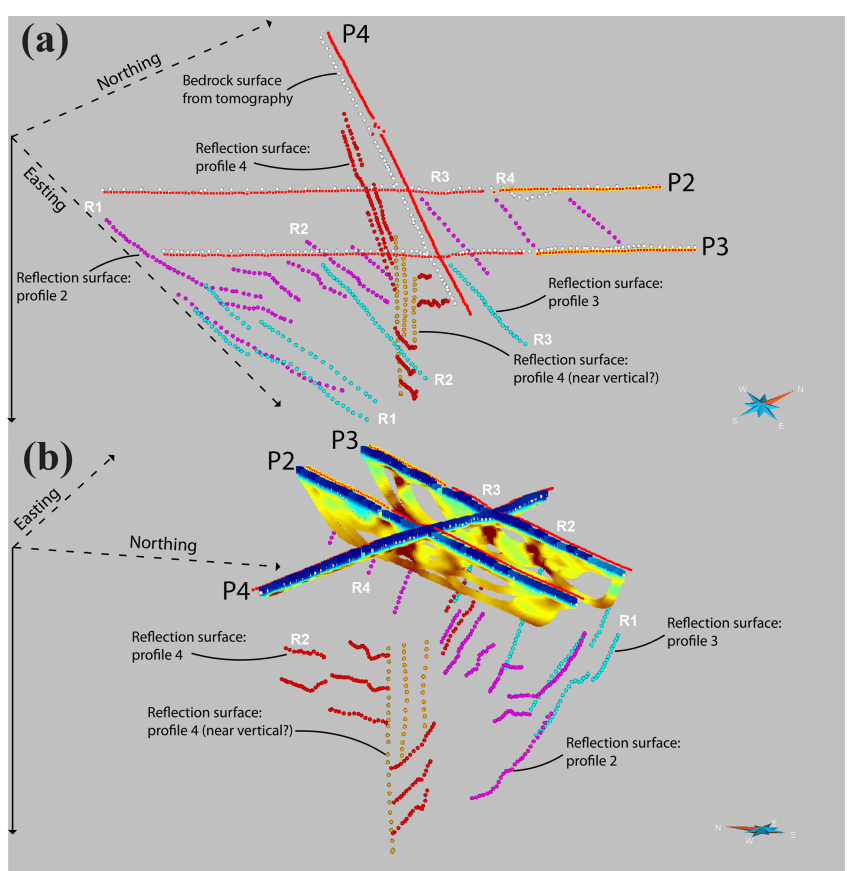

Figure 13. 3-D views showing the interpreted bedrock surface (white points), reflections from profile 2 (purple points), profile 3 (blue points) and profile 4 (red and brown points, likely vertical faults). Note that the red/yellow points on the surface represent the actual locations of the seismic sensors.

ning in NE-SW, also observed on local magnetic map of the area, not shown here) intersected in the central part of profile 4 has some control over this in the region between reflections R3 and R4. Overall, reflections (R1-R4) reasonably match the orientation of the water flow, although this study cannot alone prove that the dykes can be steeply dipping or subvertical; both scenarios would satisfy such an observation.

\subsection{Magnetic susceptibility transects across the dykes}

Because no further downhole logging was possible in the boreholes drilled in the study area, we decided to revisit the rock quarry north of the site (Figs. $2 \mathrm{a}$ and 3 ) to conduct a series of magnetic susceptibility measurements in order to check if amphibolites and dolerite dykes have comparable magnetic properties. Dolerite dykes showed much stronger magnetic susceptibility (Fig. 15) than the amphibolites and hence should be identifiable on this basis - their magnetic properties (as also evident on the magnetic map). One important observation is also that the amphibolites tend to generally gently dip towards the SW (Figs. 2a and 15), and this is inconsistent with the reflection orientations we observed in the data. The two dolerite dykes observed in Fig. 15 crosscut the gneissic and amphibolitic rocks, and the major one (approximately $5 \mathrm{~m}$ thick) appears also to be dipping at about $60-65^{\circ}$ towards the NE. In these measurements, two impor- 


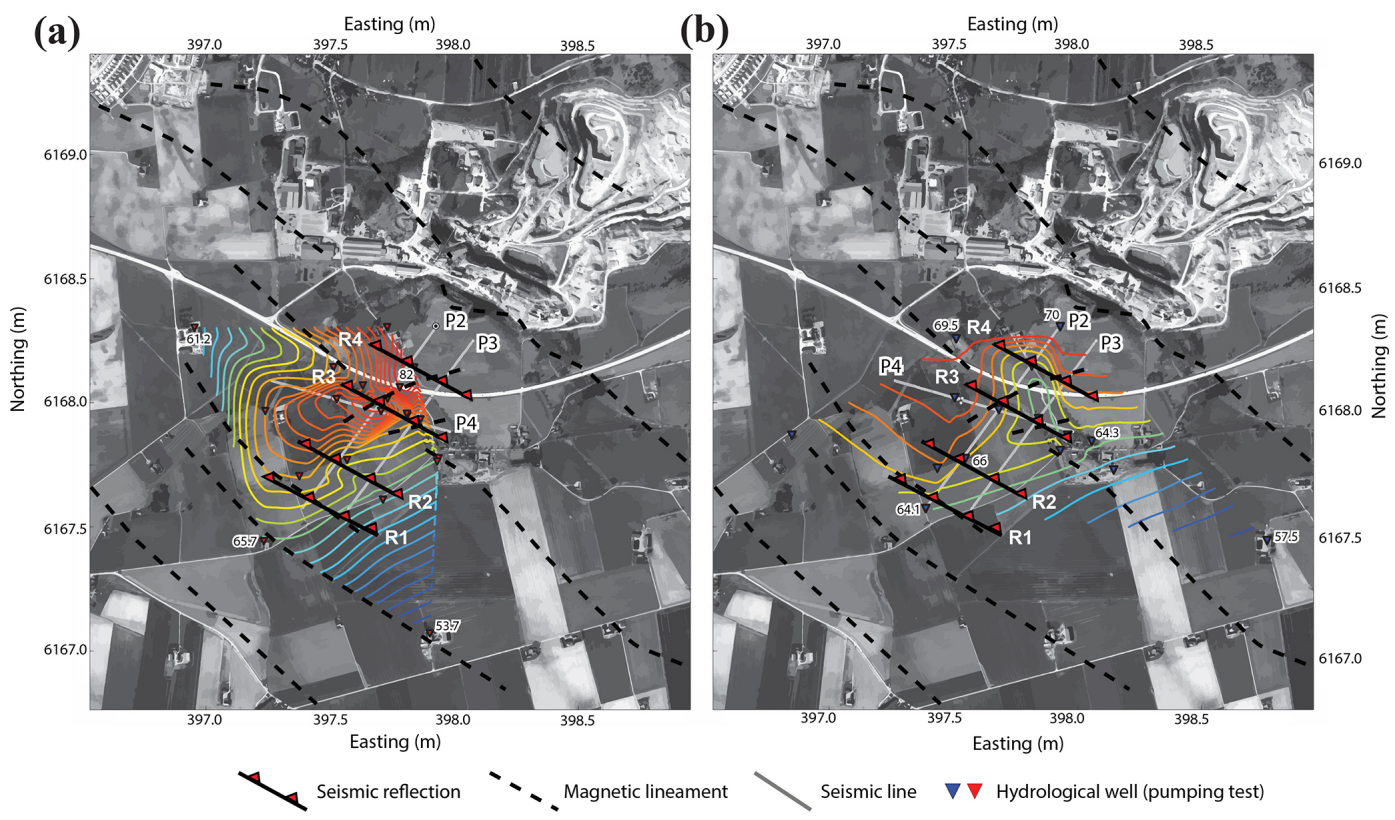

Figure 14. Hydrological measurements conducted at the site to better understand groundwater flow in (a) sediments and (b) bedrock, and if they can be connected to any underlying geology controlling their patterns. Red contours indicate high water table values and blue lower water table values. Water table values (ranging from 53 to $82 \mathrm{~m}$ elevation) are shown at a few places. The reflections observed in the seismic data are labeled as R1-R4. In the case of bedrock, a clear NW-SE groundwater flow is notable in the region where R1-R2 are observed, which may indicate the role of the steeply dipping dykes in this region. Dashed lines are the peaks of the magnetic lineaments extracted from the aeromagnetic data (Fig. 1a) from the study area. We interpret a local fault running near and parallel to profile 2 and responsible for the $\mathrm{NE}-\mathrm{SW}$ trend of the water flow in the bedrock between reflections R3 and R4.

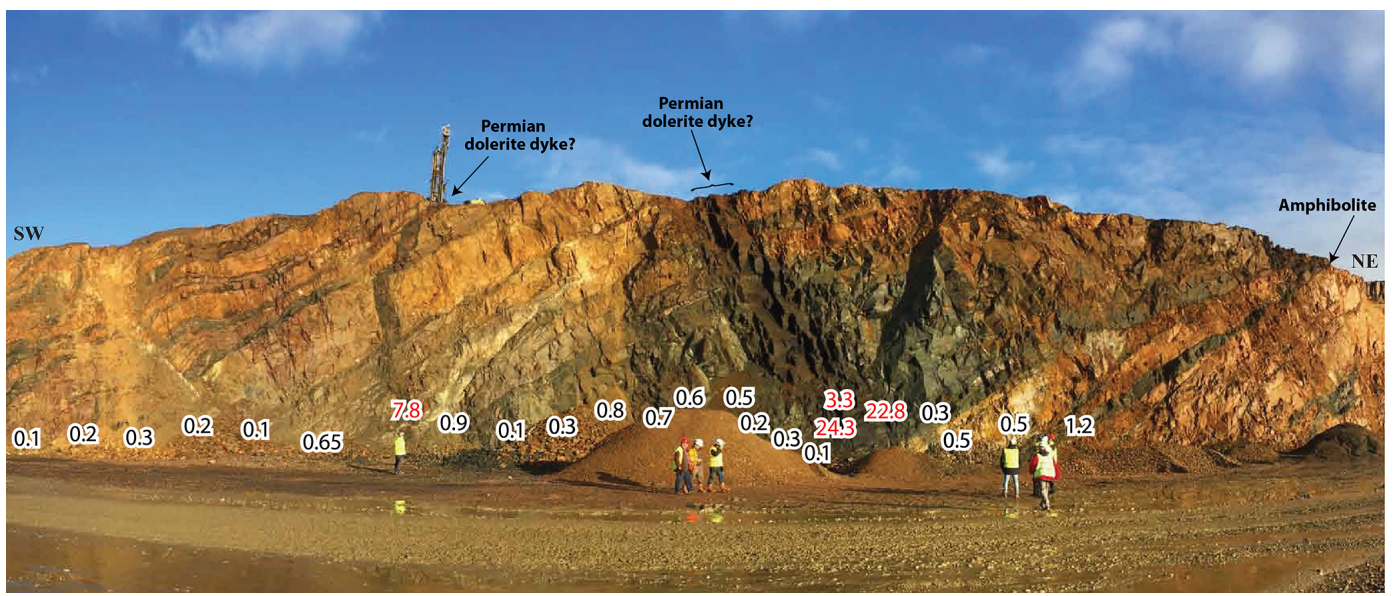

Figure 15. Magnetic susceptibility measurements (average of three to five readings at each point is shown) across a section of the rock quarry north of the study area showing how strongly magnetic (orders of 3-25 higher) the Permian dolerite dykes are compared to the other country rocks (e.g., amphibolite and gneiss) in the area. The main dyke observed here has a NE dip component similar to those observed in the reflection seismic data. Magnetic susceptibilities are shown as $10^{-3}$ SI units (e.g., 22.8 becomes 0.0228 in the SI unit). An SM20 handheld susceptibility meter was used for these measurements.

tant observations were made, namely (1) the Permian dykes occasionally have dip character similar to that of the seismic data, i.e., not necessarily subvertical everywhere, and (2) they are the only magnetic features in the area.

\subsection{Revisiting BABEL offshore seismic lines A-AA-AB}

It became immediately evident to us to check if other similar types of datasets can also provide information on the deeper geometry of the Permian dykes within the Tornquist zone. We decided to revisit the BABEL offshore seismic data from 


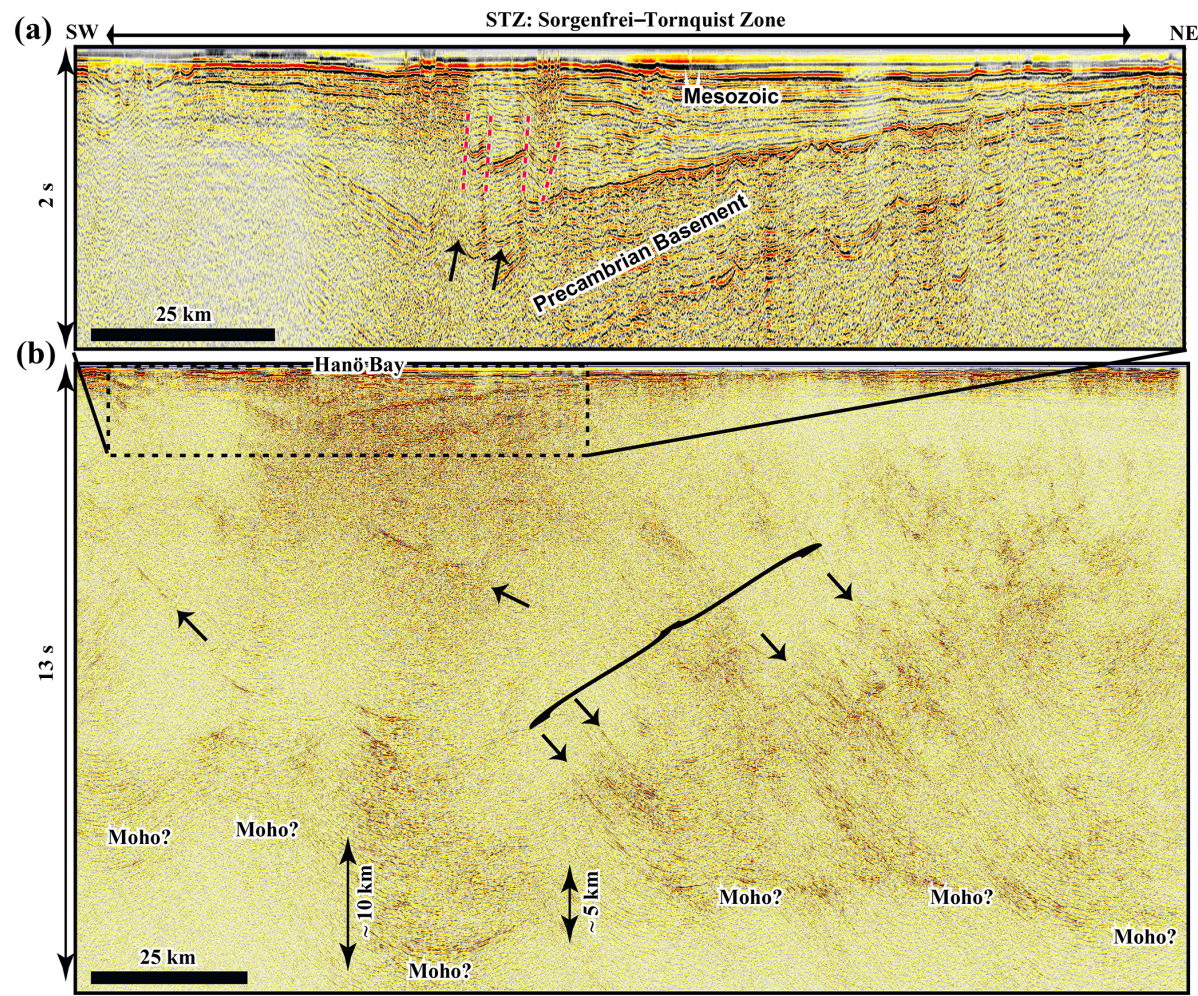

Figure 16. Reprocessed (only poststack processing) and migrated seismic section of BABEL offshore lines A-AA-AB (BABEL Working Group, 1993) across the Sorgenfrei-Tornquist Zone (a) Hanö Bay basin area. The whole seismic section is shown in panel (b), including a clear Moho step under the Hanö Bay basin. Clear faults are evident in the Hanö Bay basin and show a throw offset as much as 200-500 $\mathrm{m}$ and a multiphase history (both reverse and normal faulting). NE-dipping reflections are dominant in the lower crust projecting to the Tornquist zone. The original work did not present such a clear Moho keel and migration was done on line drawings likely using a 1-D or constant velocity model (BABEL Working Group, 1990).

the Hanö Bay basin and check if any evidence of dyke emplacement could be found in the Precambrian basement. Sediments in the Hanö Bay basin are of Mesozoic age and therefore cannot contain any Permian dykes. They can, however, provide information on faulting history within the Tornquist zone. Processed stacked sections of lines A-AA-AB (Fig. 1) from the BABEL Working Group (1990) were merged and used for this purpose. Low frequencies judged to be noise below $5 \mathrm{~Hz}$ and remaining from the original stacks were first filtered out; coherency of the reflections was then slightly improved using a FX deconvolution filter (50 traces as filter length), and then migration using a 2-D velocity model was attempted. To check the migration process, we used a number of diffractions observed on the northeastern parts of the merged section as well as the rough geometry of the basement producing edge diffractions or bow ties and examined if they collapsed to a point and did not look too over- or under-migrated. This was particularly important for the area under Hanö Bay given the rapid change from sedimentary to crystalline rocks. Figure 16 shows the resulting image for the whole section of $13 \mathrm{~s}$ data and the top $2 \mathrm{~s}$ for the Hanö Bay basin region. While multiples are still evident in the seis- mic section, the Precambrian basement manifests itself as a highly undulating surface (Fig. 16a). Two short segments of reflections are clearly notable around $700 \mathrm{~ms}$ time (between the red dashed lines) and likely have basement origins (about $200 \mathrm{~ms}$ or approximately $200-500 \mathrm{~m}$ throw). The faults also appear to show a multiphase history with both compression (thrusting) and extension (normal faulting). Apart from this, there is no evidence of steep dykes in the basement.

Looking into the deeper parts of the section (Fig. 16b), we clearly realize the Moho definition (transition from a highly reflective lower crust to transparent solidified, seismically homogenous upper mantle) around $12 \mathrm{~s}$ (approximately 45$50 \mathrm{~km}$ depth) and a clear Moho step (keel of approximately 5-10 km high and 30-40 km wide) under the Hanö Bay basin (slightly inclined towards its southwest half). While there are a number of NE-dipping reflections projecting towards the location of the Sorgenfrei-Tornquist Zone in the lowermiddle crust, we cannot be sure if these are dykes or frozen magma chambers that fed the dykes in the upper crust within the Tornquist zone. Some strong dipping reflections are also evident under the Hanö Bay basin (marked with arrows) in the crystalline middle-upper crust but again not evident if 


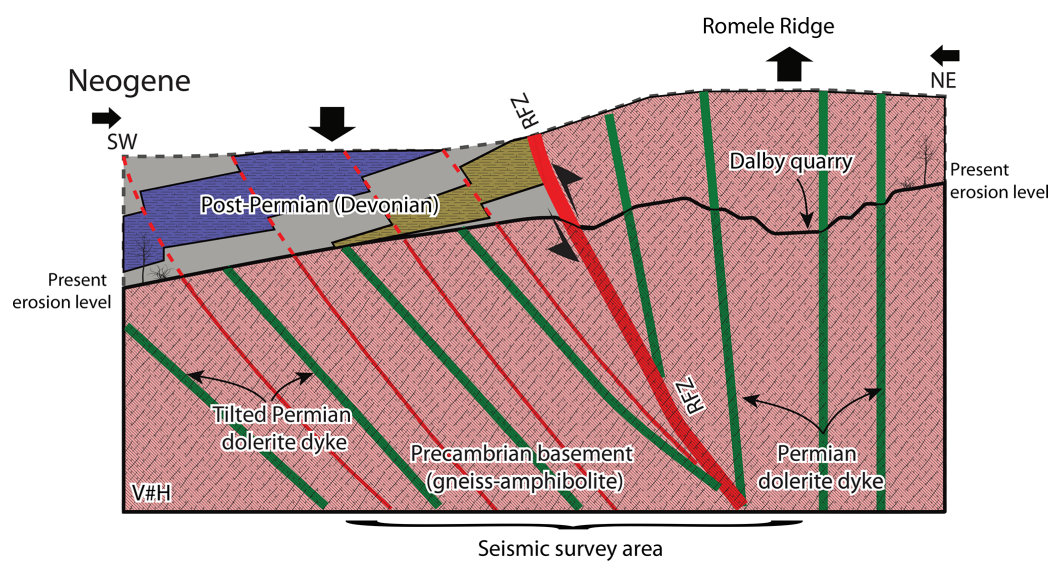

Figure 17. A simplified tectonic model (Neogene-now) illustrating our preferred scenario (see also Erlström et al., 2001) showing why the Permian dykes exhibit steeply dipping character south of the Dalby rock quarry. We associate this with a block rotation of the basement rocks immediately south of the quarry or near it (situated in the Romele Ridge) that led to the tilting of the dykes from a subvertical position to steeply dipping towards the northeast. Note that we expect some sedimentary rocks to be present south of the RFZ.

they can be connected to the dolerite dykes within the Tornquist zone in similar character and geometry as observed on the magnetic data, or they represent local dykes intruded into the crust.

\subsection{Tectonic model and implication for thermal storage}

There are two scenarios that may explain imaging the Permian dykes in the seismic data. Firstly, they are not subvertical everywhere within the Tornquist zone and they quickly turn steeply dipping in the subsurface as also observed at a few quarries in the area (see Fig. 15, where a dolerite dyke is labeled in the middle of the figure; see also Sivhed et al., 1999). Secondly, and according to our preferred scenario, the region immediately south of the quarry is strongly influenced by the RFZ (thrusting during the Cretaceous-Neogene compressive tectonic regime), so it has led to a block rotation of the basement rocks including the Permian dykes (Fig. 17). This has turned the dykes from being subvertical in most places to steeply dipping and tilted towards the NE. The study area is located nearly at the edge of the RFZ, and hence it is possible that the seismic profile crosses the fault zone or is very close to it. Such a scenario is also consistent with what is suggested by Sivhed et al. (1999) and Erlström and Sivhed (2001): immediately south of the RFZ, faults and dykes dip towards the NE as a result of basement tilting. Again, for the reasons mentioned earlier, we think that the reflections originated from the Permian dykes and not faults nor amphibolite lenses. Figure 17 provides a simplified tectonic sketch of our preferred scenario illustrating this interpretation.

The main implication of our interpretation of the dipping dolerite dykes instead of the subvertical ones is that the storage site (if it has a diameter greater than 100-200 m) may be intersected by one of these dykes. Given that the dyke- country rock contacts are likely highly water bearing, they can have a great influence on the underground water flow and hydrogeology of the subsurface. If these dykes intersect the storage, then the dykes would not act as a barrier for the water (to contain the water or fluids to be used for the thermal energy storage) but rather complicate potential leakage and fluid removal in case any leakage occurs. If building a storage site would become a reality again, core drilling, a 3-D seismic survey and appropriate downhole logging (including magnetic susceptibility) should be done. Crosshole and vertical seismic profiling (VSP) measurements can also be done to provide greater details in the subsurface. Given that Phillips et al. (2017) and this study both observe the dolerite dyke swarm, N-NE-dipping, large-scale high-fold seismic transects across the Tornquist zone would be important, since they may imply a major magma source region towards the south, which fed a more than $500 \mathrm{~km}$ radius dyke swarm system (Fig. 1).

\section{Conclusions}

In this study, we have acquired three high-resolution seismic profiles with a primary objective of characterizing an underground thermal energy storage site in the southwest of Sweden within the Sorgenfrei-Tornquist Zone. A number of boreholes were drilled following the seismic study and provided a better constraint for the interpretation of the seismic data. Clear refracted and reflected arrivals were identified in the data and allowed a clear delineation of bedrock surface and structures within it that are important for the geological storage and tectonic evolution of the site. We argue that majority of the reflections, $60-65^{\circ} \mathrm{NE}$ dipping, originated from the Permian dolerite dykes, some of which acted as planes where thrusting occurred. They spatially appear in a regular 
order and are consistent from one profile to another. Given that in most places these dykes are observed as subvertical, these seismic reflection images would then be the first time they are shown in such a steeply dipping character. We think the steeply dipping dykes have been tilted from a subvertical position due to the thrusting of the RFZ immediately located south of the Dalby rock quarry. Its implication for locating a thermal storage can be that these dykes would then be encountered if the storage has a radius larger than $100 \mathrm{~m}$. The dyke-country rock contacts are likely highly water bearing and hydraulically conductive; hence, the dykes may not act as a barrier but rather a fluid leaking zone. Most of these dykes have also intruded into the earlier faults formed during extension/rifting phases within the Tornquist zone, implying they may potentially be zones of weaknesses for construction purposes.

To complement this study, historical offshore BABEL seismic data across the Sorgenfrei-Tornquist Zone were also revisited. The new processing work conducted on poststack sections of lines A-AA-AB led to a better recognition of the Moho and its necking character $(5-10 \mathrm{~km}$ of Moho step across $30-40 \mathrm{~km}$ wide zone) under the Tornquist zone. While several others have suggested this, it is greatly evident in the revisited seismic section in this study because of better handling the poststack migration and improving coherency of the reflections. A number of faults and their kinematics (normal and reverse) have also been inferred within the Hanö Bay basin providing compelling evidence of the multiphase history of the Tornquist zone (tectonic inversion). Moreover, a series of NE-dipping reflections observed in the lower crust projecting towards the Tornquist zone is interpreted to be related to the dyke swarm within the Tornquist zone although this cannot be proved in this study and requires further studies.

Data availability. Original data underlying the material presented are available by contacting the corresponding author.

Author contributions. AM, RS and BA designed the study; AM wrote the main content and performed the seismic data processing. $\mathrm{BB}$ and $\mathrm{MJ}$ contributed with the ground magnetic, downhole and hydrological data. All authors contributed to the discussion and interpretation of the results.

Competing interests. The authors declare that they have no conflict of interest.

Special issue statement. This article is part of the special issue "Advances in seismic imaging across the scales". It is a result of the 14th International Symposium on Deep Seismic Profiling of the Continents and their Margins, Kraków, Poland, 17-22 June 2018.
Acknowledgements. This work was supported by Skanska Sweden and from benefited collaborations among experts from Sweco, Lund University and Skanska. The Trust project (http://www.trust-geoinfra.se; last access: 6 December 2018) supported mainly by Formas (2012-1907), BeFo, SBUF, Geological Survey of Sweden (SGU) and Skanska, helped to initiate this project. We thank Skanska for collaborating with us on this project, as well as the $\mathrm{PhD}$ and MSc students from Uppsala University who took part in the data acquisition and preparation of the data. This project was initiated as a spin-off of Trust-GeoInfra (http://trust-geoinfra.se/; last access: 6 December 2018) project, where both Skanska and Uppsala University were partners in the Trust 2.2 subproject. BABEL data along lines A-AA-AB were revisited through a Swedish Research Council (VR) grant (2015-05177) for which we are thankful. We thank Richard Hobbs for providing access to the original BABEL seismic lines. We thank two anonymous reviewers, along with Mariusz Majdanski and Craig Magee, as well as the topical editor, who provided critical and useful comments that improved an earlier version of this article.

Edited by: Michal Malinowski

Reviewed by: Mariusz Majdanski and two anonymous referees

\section{References}

Alva, G., Lin, Y., and Fang, G.: An overview of thermal energy storage systems, Energy, 144, 341-378, 2018.

BABEL Working Group: Evidence for Early Proterozoic plate tectonic from seismic reflection profiles in the Baltic Shield, Nature, 348, 34-38, 1990.

BABEL Working Group: Deep seismic reflection/refraction interpretation of BABEL A and B in the southern Baltic Sea, Geophys. J. Int., 112, 325-343, 1993.

Bergerat, F., Angelier, J., and Andreasson, P.-G.: Evolution of paleostress fields and brittle deformation of the Tornquist Zone in Scania (Sweden) during PermoMesozoic and Cenozoic times, Tectonophysics, 444, 93-110, 2007.

Blundell, D. J.: Deep crustal structural expression of strike-slip faulting and inversion in the Tornquist Zone, southern Baltic Sea, edited by: Meissner, R., The BABEL Project: First Status Report, Commission of the European Communities, DirectorateGeneral Science, Research and Development, Brussels, 109-112, 1992.

Cocks, L. R. M. and Torsvik, T. H.: Baltica from the Late Precambrian to mid-Palaeozoic times: The gain and loss of a terrane's identity, Earth Sci. Rev., 72, 39-66, 2005.

Dehghannejad, M., Bauer, T., Malehmir, A., Juhlin, C., and Weihed, P.: Crustal geometry of the central Skellefte district, northern Sweden-constraints from reflection seismic investigations, Tectonophysics, 524-525, 87-99, 2012.

Erlström, M. and Sivhed, U.: Intra-cratonic dextral transtension and inversion of the southern Kattegat on the southwest margin of Baltica - Seismostratigraphy and structural development, Geological Survey of Sweden, Research Papers C 832, 2001.

Erlström, M., Thomas, S. A., Deeks, N., and Sivhed, U.: Structure and tectonic evolution of the Tornquist Zone and adjacent sedimentary basins in Skåne and the southern Baltic Sea area, Tectonophysics, 271, 191-215, 1997. 
Grad, M., Guterch, A., and Mazur S.: Seismic refraction evidence for continental structure in the central part of the Trans-European Suture Zone in Poland, in: Palaeozoic Amalgamation of Central Europe, edited by: Winchester, J. A., Pharaoh, T. C., and Verniers, J., Geological Society of London Special Publication, 201, 295-309, 2002.

Guterch, A. and Grad, M.: Lithospheric structure of the TESZ in Poland based on modern seismic experiments, Geol. Q., 50, 2332, 2006.

Håkansson, U.: Thermal energy storage - TES, the underground space challenge, presented at NovaFoU, Kalmar, Sweden, available at: http://www.nova.artisan.se/documents/nova/documents/ novafou/ngl-konferens2016/ulfhakansson_skanska.pdf (last access: 8 August 2018), 2016.

Heeremans, M., Faleide, J. I., and Larsen, B. T.: Late Carboniferous-Permian of NW Europe: an introduction to a new regional map, Geological Society of London Special Publication, 223, 75-88, https://doi.org/10.1144/GSL.SP.2004.223.01.04, 2004.

Inglesi-Lotza, R. and Dogan, E.: The role of renewable versus nonrenewable energy to the level of $\mathrm{CO}_{2}$ emissions a panel analysis of sub-Saharan Africa's Big 10 electricity generators, Renew. Energ., 123, 36-43, 2018.

International Energy Agency: World energy investment 2018, available at: http://www.iea.org/wei2018/ (last access: 6 December 2018), 2018.

Juhlin, C.: Interpretation of the reflections in the Siljan Ring area based on results from the Gravberg-1 borehole, Tectonophysics, 173, 345-360, 1990

Malehmir, A. and Belleflur, G.: Reflection seismic imaging and physical properties of base-metal and associated iron deposits in the Bathurst Mining Camp, New Brunswick, Canada, Ore Geol. Rev., 38, 319-333, 2010.

Malehmir, A., Andersson, M., Lebedev, M., Urosevic, M., and Mikhaltsevitch, V.: Experimental estimation of velocities and anisotropy of a series of Swedish crystalline rocks and ores, Geophys. Prospect., 61, 153-167, 2013.

Malehmir, A., Heinonen, S., Dehgahnnejad, M., Heino, P., Maries, G., Karell, F., Suikkanen, M., and Salo, A.: Landstreamer seismics and physical property measurements in the Siilinjärvi openpit apatite (phosphate) mine, central Finland, Geophysics, 82, B29-B48, 2017.

Malinowski, M., Gutercha, A., Peteckib, Z., Janik, Środa, T.P., Maksym, A., Probulski, J., Gradd, M., Czubaa, W., Gaczyńskia, E., Majdańskia, M., and Jankowski, L.: Geophysical constraints on the crustal structure of the East European Platform margin and its foreland based on the POLCRUST-01 deep reflection seismic profile, Tectonophysics, 653, 109-126, 2015.

Mazur, S., Mikolajczak, M., Krzywiec, P., Malinowski, M., Buffenmyer, V., and Lewandowski, M.: Is the Teisseyre Tornquist Zone an ancient plate boundary of Baltica?, Tectonics, 34, 2465-2477, 2015

Meissner, R. and Krawczyk, C. H.: Caledonian and Proterozoic terrane accretion in the southwest Baltic Sea, Tectonophysics, 314, 255-267, 1999.

Meissner, R., Thybo, H., and Abramovitz, T.: Interwedging and inversion structures around the trans-European suture zone in the Baltic Sea, a manifestation of compressive tectonic phases, Tectonophysics, 360, 265-280, 2002.
Obst, K. and Katzung, G.: Spatial distribution and emplacement features of Permo-Carboniferous dykes at the southwestern margin of the Fennoscandian Shield, in: Dyke Swarms - Time Markers of Crustal Evolution, edited by: Hanski, E., Mertanen, S., Ramo, T., and Vuollo, J., Taylor \& Francis, London, 257-272, 2006.

Planke, S. and Cambray, H.: Seismic properties of flood basalts from hole 917A downhole data, Southeast Greenland Volcanic Margin, Proc. ODP Sci. Results, Ocean Drilling Program (ODP), USA, 453-462, 1998.

Planke, S., Rasmussen, T., Rey, S., and Myklebust, R.: Seismic characteristics and distribution of volcanic intrusions and hydrothermal vent complexes in the Vøring and Møre basins, Geological Society, London, petroleum geology conference series, Geological Society of London, UK, 833-844, 2005.

Pegrum, R. M.: The extension of the Tornquist Zone in the Norwegian North Sea, Norsk Geol. Tidsskr., 64, 39-68, 1984.

Pilebro, H., Strand, T., and Vestin, R.: Thermal energy storage system comprising a combined heating and cooling machine and a method for using the thermal energy storage system, United States Patent, Patent No. US 9.518.787 B2, 2016.

Phillips, T. B., Magee, C., Jackson, C. A.-L., and Bell, R. E.: Determining the three-dimensional geometry of a dike swarm and its impact on later rift geometry using seismic reflection data, Geology, 46, 119-122, 2017.

Place, J. A. P., Malehmir, A., Högdahl, K., Juhlin, C., and Persson Nilsson, K.: Seismic characterization of the Grängesberg iron deposit and its mining-induced structures, central Sweden, Interpretation, 3, SY41-SY56, 2015.

Salisbury, M. H., Harvey, C. W., and Matthews, L.: The acoustic properties of ores and host rocks in hardrock terranes, in: Hardrock Seismic Exploration, edited by: Milkereit, B., Eaton, D., and Salisbury, M., Tulsa, Oklahoma, SEG, 9-19, 2003.

Sivhed, U., Wikman, H., and Erlström, M.: Beskrivning till berggrundskartorna 1C Trelleborg NV och NO samt 2C Malmö SV, SO, NV och NO. Geological Survey of Sweden, Sweden, Reprot numbers Af 191, 192, 193, 194, 196, 198, 143 pp., 1999.

Skanska Sverige AB: Thermal energy storage with an expansion space, Patent number 9823026, 2013.

Sopher, D., Erlström, M., Bell, N., and Juhlin, C.: The structure and stratigraphy of the sedimentary succession in the Swedish sector of the Baltic Basin: New insights from vintage 2D marine seismic data, Tectonophysics, 676, 90-111, 2016.

Thybo, H.: Crustal structure and tectonic evolution of the Tornquist Fan region as revealed by geophysical methods, Bull. Geol. Soc. Den., 46, 145-160, 2000.

Torsvik, T. H., Smethurst, M. A., Burke, K., and Steinberger, B.: Long term stability in deep mantle structure: Evidence from the $\sim 300 \mathrm{Ma}$ Skagerrak-Centered Large Igneous Province (the SCLIP), Earth Planet. Sc. Lett., 267, 444-452, 2008.

Tryggvason, A., Rögnvaldsson, S. T., and Flovenz, Ó. G.: Three dimensional imaging of $\mathrm{P}$ - and $\mathrm{S}$-wave velocity structure and earthquake locations beneath southwest Iceland, Geophys. J. Int., 151, 848-866, 2002.

Yilmaz, O.: Investigations in Geophysics Seismic Data Analysis: Processing, Inversion, and Interpretation of Seismic Data, Book by the Society of Exploration Geophysicists (SEG), Tulsa, Oklahoma, 2001. 